\title{
Mountain permafrost: development and challenges of a young research field
}

\author{
Wilfried HAEBERLI, ${ }^{1}$ Jeannette NOETZLI, ${ }^{1}$ Lukas ARENSON, ${ }^{2}$ Reynald DELALOYE, ${ }^{3}$ \\ Isabelle GÄRTNER-ROER, ${ }^{1}$ Stephan GRUBER, ${ }^{1}$ Ketil ISAKSEN, ${ }^{4}$ Christof KNEISEL, ${ }^{5}$ \\ Michael KRAUTBLATTER, ${ }^{6}$ Marcia PHILLIPS ${ }^{7}$
}

\author{
${ }^{1}$ Glaciology, Geomorphodynamics and Geochronology, Department of Geography, University of Zürich-Irchel, \\ Winterthurerstrasse 190, CH-8057 Zürich, Switzerland \\ E-mail: wilfried.haeberli@geo.uzh.ch \\ ${ }^{2}$ BGC Engineering Inc., 1045 Howe Street, Vancouver, British Columbia V6Z 2A9, Canada \\ ${ }^{3}$ Department of Geosciences, University of Fribourg, CH-1700 Fribourg, Switzerland \\ ${ }^{4}$ Meteorology and Climatology Division, Norwegian Meteorological Institute, PO Box 43, Blindern, NO-0313 Oslo, Norway \\ ${ }^{5}$ Department of Physical Geography, University of Würzburg, D-97074 Würzburg, Germany \\ ${ }^{6}$ Geomorphological and Environmental Research Group, Department of Geography, University of Bonn, \\ Meckenheimer Allee 166, D-53115 Bonn, Germany \\ ${ }^{7}$ WSL Institute for Snow and Avalanche Research SLF, Flüelastrasse 11, CH-7260 Davos-Dorf, Switzerland
}

\begin{abstract}
An overview is given of the relatively short history, important issues and primary challenges of research on permafrost in cold mountain regions. The systematic application of diverse approaches and technologies contributes to a rapidly growing knowledge base about the existence, characteristics and evolution in time of perennially frozen ground at high altitudes and on steep slopes. These approaches and technologies include (1) drilling, borehole measurement, geophysical sounding, photogrammetry, laser altimetry, GPS/SAR surveying, and miniature temperature data logging in remote areas that are often difficult to access, (2) laboratory investigations (e.g. rheology and stability of icerock mixtures), (3) analyses of digital terrain information, (4) numerical simulations (e.g. subsurface thermal conditions under complex topography) and (5) spatial models (e.g. distribution of permafrost where surface and microclimatic conditions are highly variable spatially). A sound knowledge base and improved understanding of governing processes are urgently needed to deal effectively with the consequences of climate change on the evolution of mountain landscapes and, especially, of steep mountain slope hazards as the stabilizing permafrost warms and degrades. Interactions between glaciers and permafrost in cold mountain regions have so far received comparatively little attention and need more systematic investigation.
\end{abstract}

\section{INTRODUCTION}

Extensive areas in cold mountain regions are in a permafrost condition, i.e. subsurface materials remain at negative ground temperatures throughout the year and can contain considerable amounts of subsurface ice. However, because such subsurface geothermal aspects and the involved ground ice are not directly visible and, hence, cannot easily be observed or measured, the phenomenon of mountain permafrost has only been recognized rather late. Despite some early local observations, systematic research essentially started in the early 1970 s. It then rapidly intensified to become an increasingly important scientific discipline. The high sensitivity of mountain permafrost to climate change and corresponding impacts on mountain landscapes and habitats therefore deserve special attention. The following overview takes a short glimpse at the historical research development and then briefly outlines the state of knowledge and future challenges of the most prominent current research themes concerning permafrost on mountain slopes.

\section{HISTORICAL RESEARCH DEVELOPMENT}

Negative annual ground temperatures and ice-rich perennially frozen ground in high-mountain regions have long been detected in a number of cases. In the Swiss Alps, for nstance, the famous railway to the Jungfraujoch built in the first years of the 20th century terminates in subzero bedrock carrying a small cold ice cap (Haefeli and Brentani, 1955), and a number of ice tunnels dug to bedrock in the summit region of the Monte Rosa massif (Fisher, 1953) clearly revealed temperatures far below $0^{\circ} \mathrm{C}$ at high-altitude ice/bedrock interfaces. The fact that highmountain peaks may be frozen to great depth, if not throughout, was hardly recognized, however, by the scientific community at that time. For a tunnel excavated for mining operations through a small rock glacier in the San Juan region, Colorado, USA, Brown (1925) described $100 \mathrm{~m}$ of frozen sediments (angular blocks) cemented by ice. Similar observations were made in the 1950s in deep excavations at the margin of a rock glacier in connection with the construction of the Grande Dixence power scheme in the Swiss Alps (Fisch and others, 1978; Fig. 1). Again, however, the presence of subsurface ice was not recognized as an obvious indicator of ice-rich permafrost and of the associated properties and processes. Moreover, although Wahrhaftig and Cox (1959) clearly recognized the importance of slow downslope motion of frozen material in their classical study of rock glaciers in the 


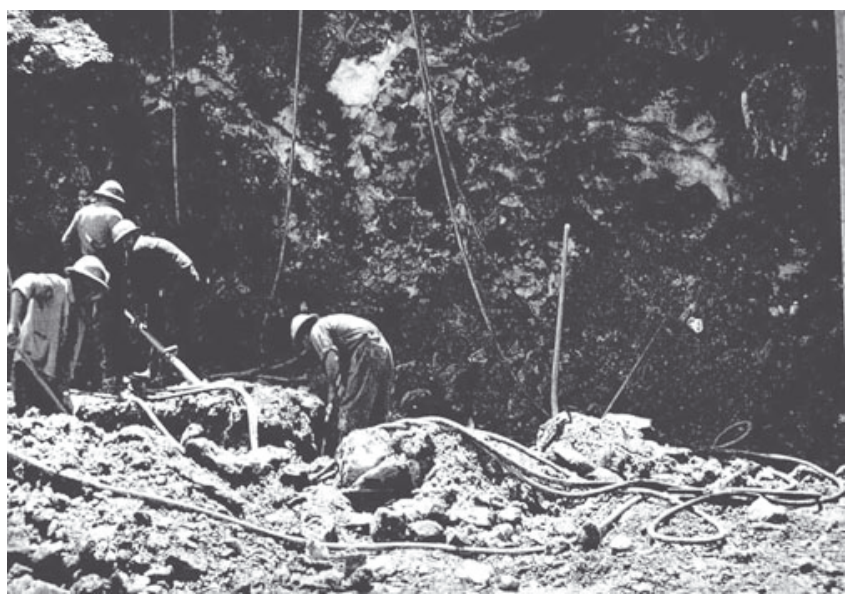

Fig. 1. Excavation of material for the construction of the Grande Dixence dam in ice-rich permafrost of a rock glacier at the locality Prafleuri, Valais Alps, Switzerland. (Photo: W. Fisch 1956; cf. Fisch and others, 1978.)

Alaska Range, they did not mention the general importance of this and related permafrost processes in other cold mountain regions.

In the late 1970s, the Proceedings of the International Permafrost Conferences started to contain papers about permafrost in mid-latitude/high-altitude mountain regions (the European Alps, the Himalaya, the Tien Shan and the Canadian Rockies; e.g. Barsch, 1978; Fujii and Higuchi, 1978; Gorbunov, 1978; Haeberli, 1978; Harris and Brown, 1978). This signalled the essential beginning of systematic research on permafrost in high-mountain areas and led to increased visibility with the International Workshop on Mountain Permafrost in Interlaken, Switzerland, in 1991. A number of overview papers on mountain permafrost and climate (Guodong and Dramis, 1992), prospecting for mountain permafrost (King and others, 1992), permafrost creep and rock glaciers (Barsch, 1992), interactions of mountain permafrost with snow, glaciers and water (Harris and Corte, 1992), surface processes in high-mountain periglacial belts (Lautridou and others, 1992) and special aspects of construction, natural hazards and environmental problems related to mountain permafrost (Haeberli, 1992) outlined the wide spectrum of the research field and opened the door to rapid expansion and progress. The potential impacts of atmospheric warming in many mountain ranges have increasingly been recognized (Haeberli and others, 1993; Jin and others, 2000; Marchenko and others, 2007).

Romanovsky and others (2007), Haeberli and Gruber (2008, 2009) and Harris and others (2009) provide recent overviews with many references documenting the state of the art. The following sections deal with ongoing research in, and primary scientific challenges related to, fields of currently the most intense research activity, i.e. (contributing authors' initials given in parentheses) occurrence and distribution patterns (S.G.), near-surface effects and microclimate (S.G. and R.D.), subsurface thermal conditions (J.N. and K.I.), geotechnical properties (L.A. and M.K.), geophysical prospection (C.K. and M.K.), long-term creep and rock glaciers (I.G.-R. and R.D.), slope stability (L.A. and S.G.), infrastructure (M.P) and climate-related monitoring (J.N. and K.I.).

\section{OCCURRENCE AND DISTRIBUTION PATTERNS}

Mountain permafrost can be found at low and high latitudes and in the Northern and Southern Hemispheres (Zhang and others, 2000). Effects of complex topography significantly influence the patterns of its occurrence (e.g. Gruber and Haeberli, 2009 and references herein). As a first-order approximation, the long-term mean annual air temperature (MAAT) can be used to delineate mountain regions and altitudinal belts with permafrost occurrences. MAAT below $-3^{\circ} \mathrm{C}$ indicates areas with significant amounts of permafrost, while a few occurrences exist around $-1^{\circ} \mathrm{C}$. This approach can be improved locally by using direct ground-based information, introducing more predictor variables (e.g. solar radiation indices) or applying physics-based models. A large body of research on the local modelling of mountain permafrost exists (review provided by Riseborough and others, 2008) and regional-scale spatial model simulations have been produced (e.g. Marchenko, 2001; Etzelmüller and others, 2003, 2007; Bonnaventure and Lewkovicz, 2008). A prominent example is the model simulation of permafrost distribution patterns in the Swiss Alps (Fig. 2), which was prepared on behalf of the Federal Office for the Environment (FOEN, 2006).

The distribution of mountain permafrost can be conceptualized with the domains climate, topography and ground conditions. Climate refers to the distribution of cold surface conditions in mountain areas at a regional scale as governed by the influence of latitude and global circulation. These conditions are modified by topography having a strong influence on microclimatology, energy fluxes and mass balance due to variations in air temperature (regional scale, altitudinal belts), solar radiation (local scale) or redistribution of snow, as an important modifying factor, by wind and avalanches (local scale). Locally, the topographically overprinted climate conditions are modified by ground properties and their influence on heat and water transfer. Coarse rock debris at the surface (e.g. talus), for instance, results in relative ground cooling when compared with bedrock or fine-grained substrate (Harris and Pedersen, 1998). High ice content can significantly slow ground warming at depth (Romanovsky and others, 2010), and the time-varying thermal properties of freezing soils and insulating effects of snow can cause ground temperatures to differ significantly from air temperatures (Hoelzle and others, 2001). In regions with continental-type climatic conditions, the periglacial belt is especially extended due to the reduced glacier cover in comparison with more humid-maritime regions. As a consequence, permafrost in cold, dry mountains can be widespread, may strongly interact with polythermal or cold glaciers and can exist beneath dense vegetation, which influences ground temperatures through its effect on evapotranspiration, soil composition, shading and snow retention. The overall magnitude of the effect of topography and ground conditions on the mean annual ground surface temperature (MAGST) can be as high as $15^{\circ} \mathrm{C}$ within a distance of $1 \mathrm{~km}$. This strong lateral heterogeneity has two further consequences: (1) The reactions to environmental changes are likely similarly heterogeneous in space and time, implying fast and sensitive reactions at some places and little or even reverse reactions at others (Fig. 7, further below). Furthermore, the interpretation of monitoring data in terms of their spatial representativeness is difficult. As a consequence, 


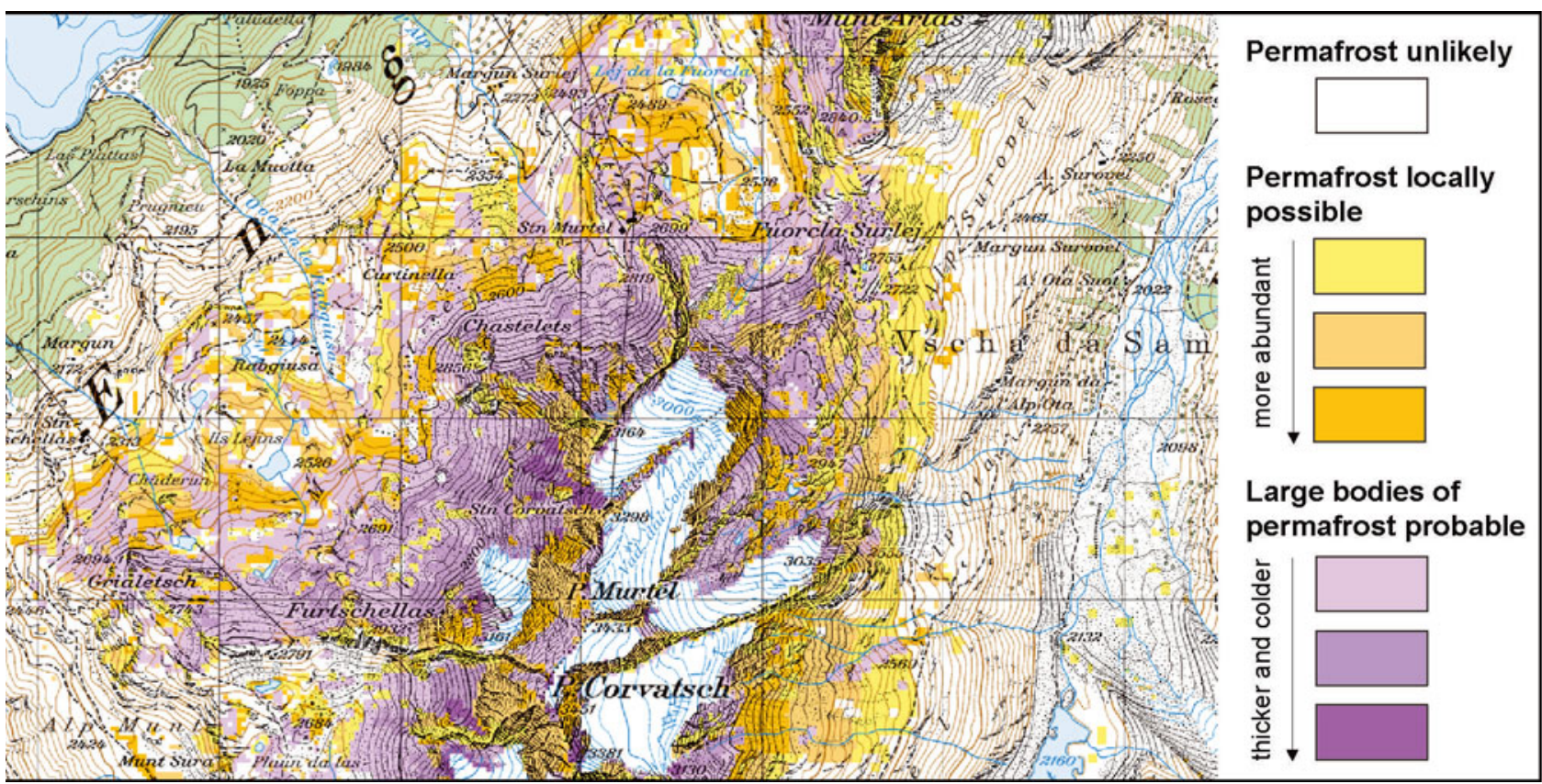

Fig. 2. Potential permafrost distribution as shown by the new Swiss Permafrost Map 1:50000 (subsection of map sheet 'Julierpass') published by the Swiss Federal Office for the Environment (FOEN) and realized by Geotest, GEO7 and Academia Engiadina (FOEN, 2006). Reproduced by permission of FOEN.

(2) the understanding of spatial heterogeneity and its influence on the temporal paths of reactions to climate change remain among the most central challenges in mountain permafrost research.

\section{NEAR-SURFACE EFFECTS AND MICROCLIMATE}

Surface energy fluxes and microclimatic conditions in highmountain permafrost differ considerably from conditions in high-latitude lowlands and are further strongly influenced by a snow cover with high lateral variability. Rock debris on steep mountain slopes is often coarse-grained and well drained. The cooling influence on ground temperatures of coarse blocks, such as typically exist on rock glacier surfaces, is mainly based on temperature-driven air convection, reduced insulation below the snow cover in spring, and the advection of latent heat by burial of snow. Because, during winter, ground temperature at depth is higher than air temperature, free convection can develop in highly permeable deposits, making atmosphere-ground coupling more effective during cold conditions (e.g. Bernhard and others, 1998; see also Goering and Kumar, 1996). Thick snow reduces convection, making this cooling mechanism most effective in areas and times with little snow. Furthermore, block layers can cause ground cooling by reducing the warming effect of the winter snow based on their low thermal conductivity (Gruber and Hoelzle, 2008). The magnitude of this second type of relative cooling is greatest in areas with thick snow cover. Snow incorporated into the ground can advect significant latent heat that is only slowly removed by heat conduction from the warming surface during summer. In coarse deposits, snow can be blown deep into the voids of the active layer (Juliussen and Humlum, 2008) in active talus slopes (Gruber and Haeberli, 2009) and volcanic areas (Kellerer-Pirklbauer and others, 2007), where scoria mixed or interlayered with snow can accumulate.
In addition to the above, temperature-driven seasonal subsurface ventilation throughout layers of coarse blocks on steep slopes can locally reduce mean ground temperatures by several ${ }^{\circ} \mathrm{C}$ (Delaloye and Lambiel, 2005; Fig. 3). Internal ventilation enables permafrost to exist beneath the foot of a slope even at locations with a MAAT several degrees above $0^{\circ} \mathrm{C}$ (Delaloye and others, 2003). Caves can accumulate ice and preserve permafrost conditions not only due to the reduction of incoming solar radiation but especially due to density-driven exchange of cold air during winter, which either terminates during summer when the cold air is trapped and stratified stably in the cave (Luetscher and others, 2005) or reverses - as throughout a talus slope -

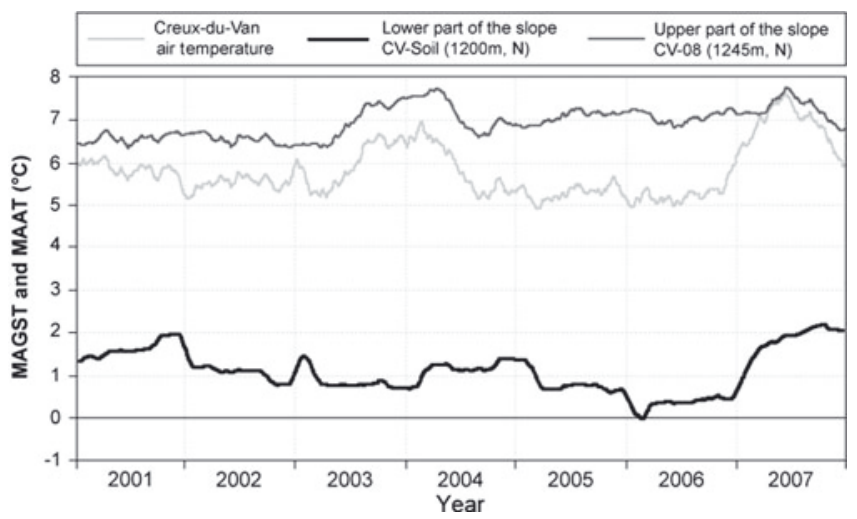

Fig. 3. Ground surface thermal anomalies in a ventilated talus slope at low elevation: Creux du Van, Jura mountains, Switzerland (1200 m a.s.l.; adapted from Morard and others, 2010b). In comparison with the MAAT (grey curve), there is (1) a strong negative thermal anomaly of MAGST in the bottom part of the slope and a slight positive anomaly in the upper part and (2) singular behaviour of the ground thermal conditions. Dates correspond to the mean value of the 12 previous months. 

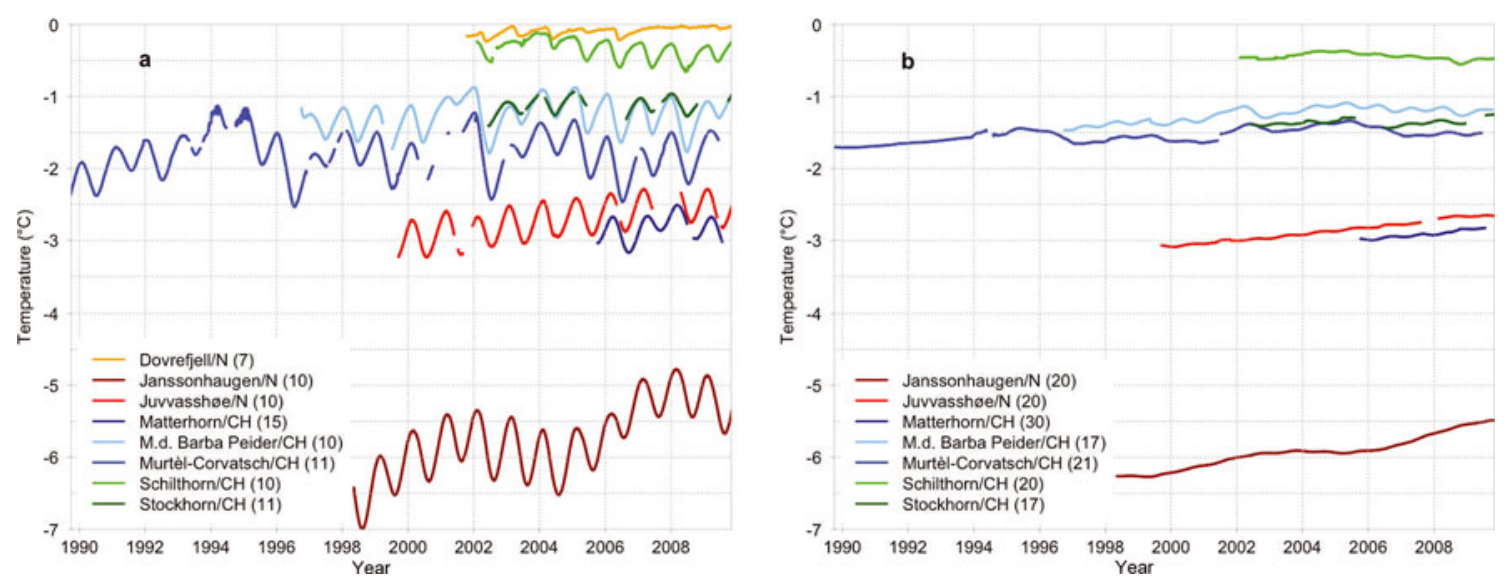

Fig. 4. Subsurface temperatures at about (a) $10 \mathrm{~m}$ and (b) $20 \mathrm{~m}$ depth and their evolution for selected boreholes in mountain permafrost: the sites of the PACE transect and two additional sites in Switzerland (Matterhorn and Muot da Barba Peider) and one in Norway (Dovrefjell). Data for Swiss sites are provided by the Swiss Permafrost Monitoring Network (PERMOS), for Norwegian sites by the Norwegian Meteorological Institute.

when a lower entrance in the cave system is open (Morard and others, 2010).

In contrast to the above-described conditions on moderately steep slopes, near-surface temperatures and their changes in very steep to vertical rock walls without thick snow are generally higher, but much more directly coupled to atmospheric conditions (Nötzli and others, 2009). In south-exposed near-vertical rock faces of the Alps, for instance, MAGST can be up to $10^{\circ} \mathrm{C}$ higher than MAAT, illustrating the strong influence of incoming solar radiation.

Despite considerable progress in research, several fundamental challenges remain concerning permafrost in steep bedrock (Gruber and Haeberli, 2007), most prominently the understanding of intermediate conditions between steep bedrock and talus slopes making up a large proportion of mountain permafrost areas. Similarly, the thermal effects of seasonal changes in thermal conductivity in rock and of snow in moderately steep rock walls are only partly understood at present.

\section{SUBSURFACE THERMAL CONDITIONS}

Ground temperatures in mountain permafrost are measured in boreholes or with near-surface miniature loggers and are typically only a few degrees below $0^{\circ} \mathrm{C}$ (e.g. Harris and others, 2003; Christiansen and others, 2010; Nötzli and others, 2010; Nötzli and Vonder Mühll, 2010; Schoeneich and others, 2010; Zhao and others 2010). In the European Alps, mean annual ground temperatures (MAGT) measured in boreholes are typically between $0^{\circ} \mathrm{C}$ and $-3^{\circ} \mathrm{C}$, with sites at very high elevation being considerably colder $\left(\sim-12^{\circ} \mathrm{C}\right.$ at the ice/bedrock interface on Colle Gnifetti, Switzerland; Haeberli and Funk, 1991; Lüthi and Funk, 2001). MAGT measured in Scandinavia are typically above $-3^{\circ} \mathrm{C}$ but can be considerably lower in polar mountain regions like Svalbard (Fig. 4)

As described in section 4, the relation between atmospheric and surface and near-surface temperatures is not straightforward and is strongly controlled by topography (aspect) and surface cover (snow, debris, bedrock). Further, as shown by Noetzli and others (2007), near-surface temperatures do not sufficiently describe the temperature distribution at depth because in colder northern (Northern
Hemisphere) flanks temperatures are often influenced by nearby mountainsides with higher temperatures. Here, lateral heat fluxes overprint the typical pattern of subsurface temperatures increasing with depth (Fig. 5). In addition to these conductive processes, other types of heat transport, such as advection by (snowmelt) water percolating along clefts, may significantly alter ground temperatures locally. The importance of jointly investigating heat and water transfer has long been recognized for lowland areas (e.g. Kane and others, 2001) and is now receiving increased attention in mountains through measurement campaigns (Rist and Phillips, 2005) and modelling (Dall'Amico and others, 2010; Scherler and others, 2010).

The propagation of changing air temperatures into the permafrost can be altered by surface cover (especially snow), delayed by effects of latent heat (e.g. at Schilthorn, Switzerland, the entire borehole profile is nearly isothermal; Fig. 4) and accelerated by three-dimensional (3-D) geometry. The latter results from both multilateral warming and shorter distances to the surface, and makes mountain permafrost react significantly faster to surface changes than does permafrost in high-latitude lowlands (Noetzli and Gruber, 2009). The range of annual temperature variation measured in the borehole on the steep Hörnliridge at the Matterhorn, Switzerland, for instance, is comparable to ranges measured at shallower depths at other sites, because the shortest distance to the surface is not to the top of the borehole (Nötzli and Vonder Mühll, 2010; Fig. 4).

Paleoclimatic effects from past cold periods, $10^{4}$ years ago or more (e.g. the last glacial period), are no longer pronounced at depths typically reached in mountain permafrost boreholes $(<100 \mathrm{~m})$. At larger depths (i.e. 500$1000 \mathrm{~m}$ ), modelling results suggest effects may still exist within a range of a few degrees (Noetzli and Gruber, 2009). This is generally lower than in permafrost areas at lower altitudes due to comparably low ice contents and the abovedescribed accelerating effect of 3-D geometry.

Effects from more recent climatic changes have been demonstrated by Isaksen and others (2007b) for the $\sim 100 \mathrm{~m}$ deep PACE (Permafrost and Climate in Europe) borehole sites in Scandinavia and Svalbard. Significant warming is detectable down to at least $60 \mathrm{~m}$ depth, and present decadal warming rates at the top of the permafrost are of 


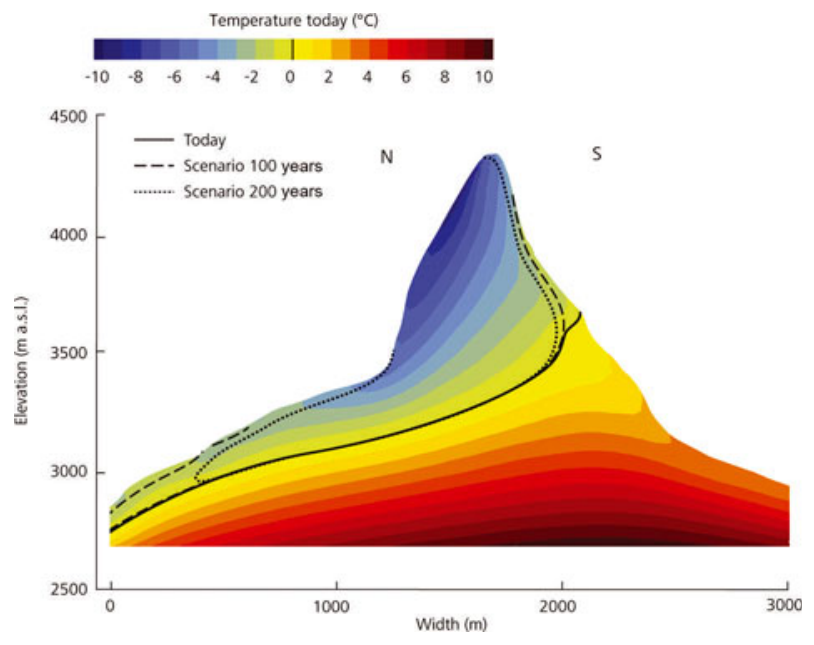

Fig. 5. Schematic visualization of the subsurface temperatures field of a north-south cross section through the Matterhorn. In addition, a simulated $0^{\circ} \mathrm{C}$ isotherm is plotted as black lines for current conditions, a warming scenario of $+3^{\circ} \mathrm{C}$ in 100 years (dashed) and $+6^{\circ} \mathrm{C}$ in 200 years (dotted). The $0^{\circ} \mathrm{C}$ isotherm can be interpreted as a schematic permafrost boundary. From Noetzli and Gruber (2009).

the order of $0.04-0.07^{\circ} \mathrm{Ca}^{-1}$, with greatest warming in Svalbard (Fig. 4). Recent findings from southern Norway show that the greatest temperature increases are found at sites with present MAGT slightly above $0^{\circ} \mathrm{C}$. This may possibly be caused by a gradual vanishing of ice due to recent permafrost degradation, leading to a drier nearsurface layer and thus changes in the near-surface heat exchange. Significant near-surface warming resulting from a remarkable temperature anomaly on Svalbard during the winter and spring of 2005/06 was reported by Isaksen and others (2007a). Mean ground temperatures at the permafrost table during 2006 were $1.8^{\circ} \mathrm{C}$ higher than the mean for the previous 6 years. Measurements in the Alps also show a slight warming trend at several measurement sites (Fig. 4), with more-or-less immediate response in active-layer thickness to extreme temperature events such as in summer 2003 (e.g. Harris and others, 2003; Phillips and others 2009; Nötzli and Vonder Mühll, 2010). Other sites, however, show no warming trends, and even cooling trends at different depths (Zenklusen Mutter and others, 2010). Temperature trends are therefore less clear than in Svalbard and Scandinavia and masked by the high interannual variations resulting from varying snow cover and other surface conditions in the complex topography. Many sites are likely modulated by latent heat exchange in warm permafrost close to $0^{\circ} \mathrm{C}$ (Nötzli and Vonder Mühll, 2010). The distinction of the individual signals and the interpretation of differing trends observed in mountain permafrost is a major challenge. The situation may become clearer with continued changes in atmospheric conditions and with longer time series. The interpretation of changes from borehole temperature profiles in steep mountains is furthermore complicated, because the effect of climatic signals also needs to be separated from geometric effects (e.g. Gruber and others, 2004). This can be partly addressed by using transient 3-D modelling approaches (Noetzli, 2008). However, given the variability of climate in the past and possibly accelerated change in the future, mountain permafrost is clearly in a transient thermal state.

\section{GEOTECHNICAL PROPERTIES}

The term permafrost, with its thermal definition, does not include information on subsurface ice and materials. Typically, however, subsurface ice conditions are of key interest to engineers and geoscientists in mountain environments. Highest priorities relate to the physical properties controlled by the ice within frozen grounds and to the change in the ground thermal regime. Corresponding research on geotechnical aspects of mountain permafrost, especially with regard to conditions on steep slopes, has strongly intensified during the past few years. Recent overviews are given by Arenson and others (2007) and Springman and Arenson (2008).

The shear strength along planes of weaknesses in permafrost-affected bedrock is susceptible to subzero temperature changes due to alterations in both rock- and ice-mechanical properties. (1) Rock strength decreases exponentially by up to $50 \%$ or even more in water/ice saturated rocks between $-5^{\circ} \mathrm{C}$ and $0^{\circ} \mathrm{C}$ (Mellor, 1973). (2) Ice-mechanical properties relevant to small rockslides may include breaking the connection between ice and rock surfaces, while those for larger rockslides (>20 m rock overburden) are governed by ductile shear deformation and fracture of ice itself (Guenzel, 2008). Both mechanisms of ice deformation respond strongly to temperature increase from $-5^{\circ} \mathrm{C}$ to $0^{\circ} \mathrm{C}$ (Sanderson, 1988; Davies and others, 2000). The importance of the overburden is evident in constant-stress experiments, as fracturing of ice only occurs above certain strain rates (Günzel, 2008). It appears that the propensity for fracturing along rock/ice contacts reduces with increasing normal stress (i.e. overburden), a behaviour that has also been observed for fracturing within ice samples (Sanderson, 1988). Ice segregation may enhance destabilization due to the creation and widening of ice-filled fractures and due to additional stress applied to the rock mass (Murton and others, 2006). Based on a Mohr-Coulomb assumption, Krautblatter (2009) defined a rock/ice mechanical failure criterion for an ice-filled rock cleft with cohesive rock bridges (Kemeny, 2003), contact of rough fracture surfaces (Barton and Choubey, 1977), ice creep (Paterson, 1994) and a representation of failure mechanisms along the rock/ice contact and within the ice body (Günzel, 2008). Magnitude is important because some processes (e.g. fracturing of rock bridges) will increase with greater normal stress (i.e. overburden), while others (e.g. ice fracturing) will decrease with increasing normal stress. On the other hand, the importance of different destabilization processes will vary considerably over time. Thawing-related changes in rockmechanical properties may significantly influence early stages of the destabilization of larger (more than several meters of rock overburden) thawing permafrost rocks (Krautblatter and Funk, 2010). This is because fracturing of ice only occurs above certain strain rates and the shear resistance exerted by the creep of ice is proportional to the strain rate and is thus extremely low at the initial speed of deformation at which, for example, subcritical cracking of rock bridges occurs. Once the deformation reaches a certain level (where significant strain is applied to ice-filled discontinuities), ice-mechanical properties outbalance the importance of rock-mechanical components.

Ground ice is affected by accretion, segregation, creep and thaw. The interaction of soil particles controls the strength of frozen soils, which on high-mountain slopes 


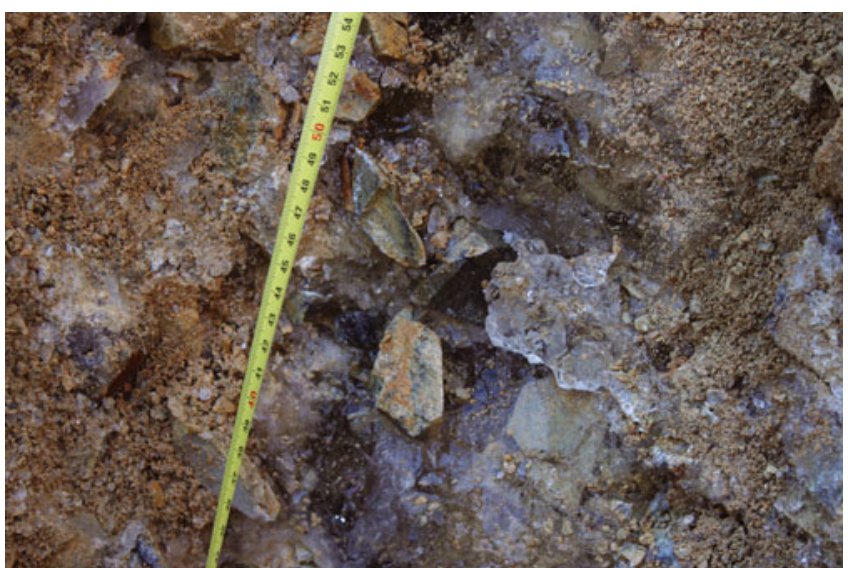

Fig. 6. Coarse-grained, ice-rich (excess ice) and saturated frozen soil found in a test pit at $\sim 3 \mathrm{~m}$ depth in an active rock glacier in the Andes. (Photo: L. Arenson 2009.)

often consist of relatively coarse, non-consolidated debris with high ice contents. The strength of such materials is similar in the frozen and unfrozen state except that the ice matrix can strongly influence the cementation. The strength properties of the matrix are strongly nonlinear and depend on temperature, loading and deformation rate (Nickling and Bennett, 1984). As a general rule, the strength of frozen grounds increases as the temperature decreases and the stress-strain behaviour changes from ductile to brittle. A slight increase in the unconfined compressive strength is noted due to ice strengthening for coarse-grained frozen sands typically found in mountainous environments and for 'dirty ice' with volumetric ice contents exceeding 40\% (Goughnour and Andersland, 1968; Arenson and Springman, 2005b). As the volumetric ice content decreases below such limits, structural hindrance between the solid particles in the frozen ground and dilatation occurs, increasing the strength and reducing creep strains significantly. At high relative soil densities, the resulting increase in strength over the same soil in its unfrozen state may be quantified as cohesion at zero stress (e.g. Arenson and others, 2004; Nater and others, 2008). However, at very large strains, ice bonding fails, destroying the cohesive effect, and the strength of the frozen material approaches that of the equivalent unfrozen soil. Volumetric air contents of up to $25 \%$ have been recorded in intact rock glacier samples (Arenson and Springman, 2005a); they resulted in volumetric strains of $>10 \%$ during triaxial compression at an axial creep strain of $20 \%$. An increase in strain rate results in an increase in frozen ground strength, but also in a change towards a brittle behaviour. Under very low strain rates, creep dominates the deformation and sample response, because complete relaxation compensates any small increase in stress caused by an added strain. The refreezing potential of preloaded frozen soils was demonstrated by Arenson and Springman (2005a), who presented tests during which the compression was stopped and broken bonds within the ice matrix were allowed to refreeze. Initial strength exceeded the values expected under comparable conditions and is thought to be caused by the refrozen ice bonds. The resistance converged towards continuous values following additional shearing with no obvious volume change. Even though saline soils are not typical for mountain permafrost environments, it is interesting to note that the strength of a frozen saline soil decreases as the salinity increases (e.g. Hivon and Sego, 1995). Arenson and Sego (2006) further showed that the ice crystal structure fragility increases with an increase in the pore fluid salinity. In summary the geotechnical behaviour of frozen soils can be described as follows:

The strength of frozen soils is higher than the strength of the unfrozen material at low confining stresses due to the cohesion contribution from the ice matrix.

Ice strength is not affected by the confinement at stresses typically found for mountain permafrost ground.

In general, peak strength increases with decreasing ice content for frozen, ice or water saturated samples in unconfined compression (e.g. Goughnour and Andersland, 1968). However, at high confining stresses, where pressure melting in shear becomes relevant, the ultimate shear strength decreases with a decrease in volumetric ice content.

The maximum value of the large strain shear strength is reached for low volumetric ice contents, where the structural hindrance is well developed and cohesion due to the ice matrix is available. In addition, the ice broadens the shear zone, which has been observed during direct shear tests and described as 'rubblisation' (Yasufuku and others, 2003).

When excess ice is present (Figs 1 and 6), perennially frozen debris or talus on slopes deforms slowly (creep) under gravitational stresses (Haeberli and others, 2006). Excess ice does not have to be present uniformly in the ground to permit creep; even thin ice layers (e.g. from segregated ice or in rock clefts) may suffice to allow the frozen debris to deform. It is therefore important to identify such ice layers during drilling, geophysical prospecting or geotechnical site investigations in order to judge the ground's susceptibility to creep even in materials with overall low ice contents and in jointed bedrock. At temperatures close to melting, the specific surface of the soil and rock particles affects the amount of water that remains unfrozen below $0^{\circ} \mathrm{C}$. Because unfrozen water is much more mobile than ice (e.g. Barnes and others, 1971; Fish, 1985), simply adopting the Arrhenius relation to characterize the temperature dependence of the rheological constants in Glen's flow law (often used in glacier dynamics; e.g. Paterson, 1994) will be invalid at temperatures close to the melting point; different approaches (e.g. Hivon and Sego, 1995) should be used for frozen ground. Creep laws and properties of various frozen materials are presented by Andersland and Ladanyi (2004). Suggestions for creep parameters in ice-rich debris can be found in Arenson and Springman (2005a). However, more data are needed to better characterize the geotechnical behaviour of ice-rich frozen ground close to $0^{\circ} \mathrm{C}$ often found in mountain slopes with discontinuous or even patchy permafrost occurrence.

\section{GEOPHYSICAL PROSPECTING}

Geophysical methods provide information on the physical properties of the subsurface, the spatial distribution of these properties and, by inference also, the structure of the subsurface. Their successful application to prospecting for permafrost is based on marked changes in physical 
properties that occur following the phase transition from an unfrozen to a frozen state. Many local investigations have been carried out for tens of years already. Hauck and Kneisel (2008) and Kneisel and others (2008) provide recent overviews.

Non- or minimally invasive geophysical sounding methods can rapidly provide information over an extended survey area, in contrast to the point-source information available from drilling. For the study of mountain permafrost in unconsolidated sediments often with small-scale heterogeneity (ranging from permafrost with low ice content to massive ground ice within meters to tens of meters) and for the study of permafrost in bedrock, two-dimensional (2-D) electrical resistivity tomography (ERT), often applied in conjunction with 2-D seismic refraction tomography (SRT), has proved to be especially well suited (e.g. Kneisel and others, 2008).

In ERT, the installation of permanent electrodes allows direct assessment of spatial and temporal permafrost variability in unconsolidated permafrost materials (Fig. 7; Hauck, 2002; Kneisel, 2006; Hilbich and others, 2008) and rock walls (Krautblatter and Hauck, 2007). Repeated seismic refraction with constant sampling geometries is capable of assessing active-layer variations in unconsolidated permafrost materials (Hilbich, 2009). Laboratory testing and multi-annual field testing by Krautblatter and Draebing (2010) indicate that refraction seismics are applicable for permafrost detection in solid rock walls, especially for the exact delineation of the active-layer depth. The recent effort by Hauck and others (2008) to quantify water, ice, air and rock debris contents in loose materials by combined ERT and refraction seismic modelling heralds a shift from qualitative to quantitative interpretation of permafrost properties. Appropriate description of the uncertainties in the inversion is of particular importance and must be considered a requirement for the quantitative interpretation of ERT images (Koestel and others, 2008). A first attempt for the quantitative application of ERT in rock walls, in particular to image the temperature distribution inside rock walls, has been undertaken by Krautblatter and others (2010). The reduction of the degrees of freedom in the interpretation of the obtained results, however, remains an important challenge.

One of the main problems in assessing future permafrost response to atmospheric warming is the lack of 3-D information relating to subsurface composition, ice content and structure (Harris and others, 2009). Here 3-D geophysical prospecting will play an important role in the near future. While 2-D ERT can be regarded as state-of-the-art for mapping and monitoring permafrost distribution and characteristics, 3-D applications are still in their infancy in the study of permafrost. This approach, however, has considerable potential to provide new insights into the small-scale subsurface heterogeneity in mountain permafrost environments.

\section{LONG-TERM CREEP AND ROCK GLACIERS}

Long-term permafrost creep is defined as the continued, slow deformation of a mass of debris supersaturated with (excess) ice (e.g. Haeberli, 1985; Barsch, 1996). The deformation rate of perennially frozen sediment is influenced by its external (slope gradient, sediment input, etc.) and internal (particle size, ice content, unfrozen water

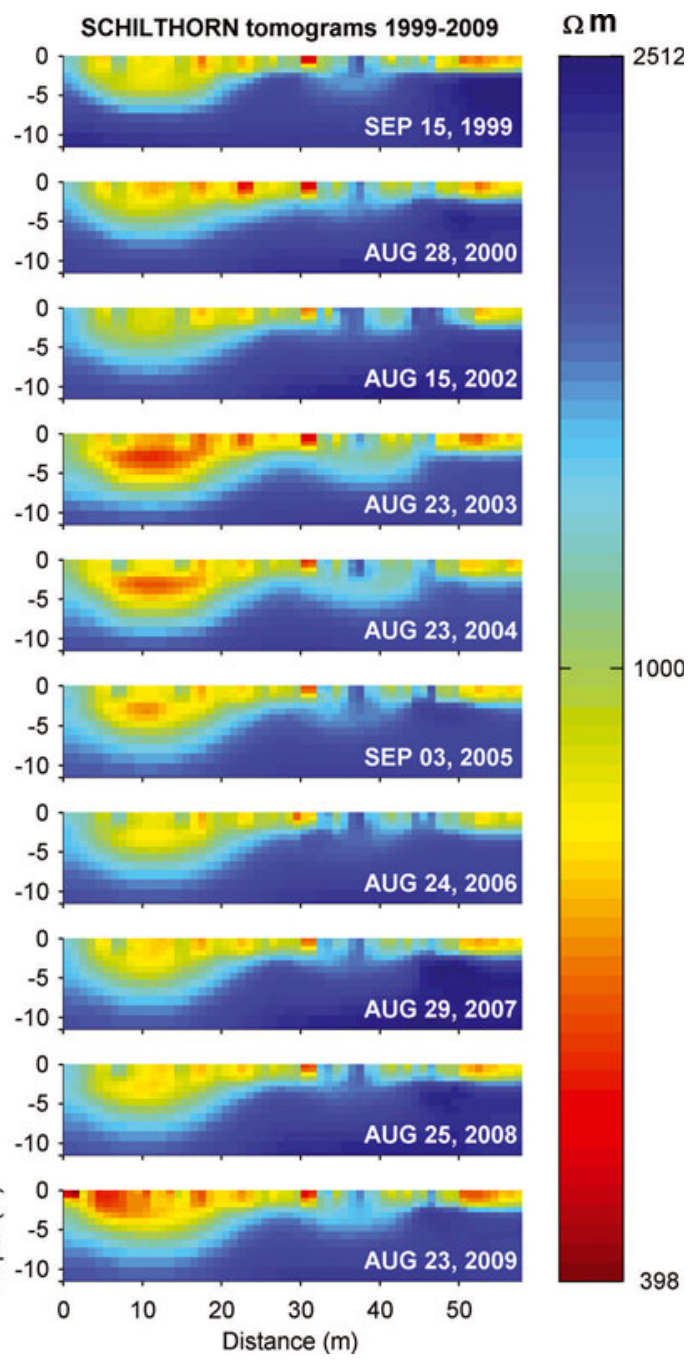

Fig. 7. ERT-monitoring results for end-of-summer measurements at Schilthorn between 1999 and 2009 (graph prepared by C. Hilbich, University of Zürich; Nötzli and others, 2009). Significant interannual resistivity changes are evident from measurements at the end of each summer. Especially in the left part of the profile, where the ground consists mainly of loose debris as opposed to bedrock in the right part, anomalously low resistivity values are detected in 2003, which persist in 2004 and only slowly increase until 2006, when the original values of 1999 are reached again (Hilbich and others, 2008). A substantial loss of subsurface ice is assumed to have taken place during summer 2003 and again in summer 2009.

content, etc.) characteristics, as well as by its temperature. Depending on these conditions, characteristic landforms of viscous flow such as rock glaciers (Fig. 8), glaciotectonically deformed ('rock-glacierized') moraines or creeping talus slopes form over periods of centuries and millennia (Haeberli and others, 1999). Based on the rich information now available from a great number of advanced field experiments and focused observations, a review paper (Haeberli and others, 2006) was recently compiled by a combined task force of the International Permafrost Association (IPA) and the International Commission on Snow and Ice (ICSI; now the International Association of Cryospheric Sciences (IACS)).

In the history of rock glacier research, encouraged by the pioneering work of Wahrhaftig and Cox (1959), first simple remeasurements of painted stone-lines and, later, geodetic surveys and different air- and spaceborne remote-sensing 


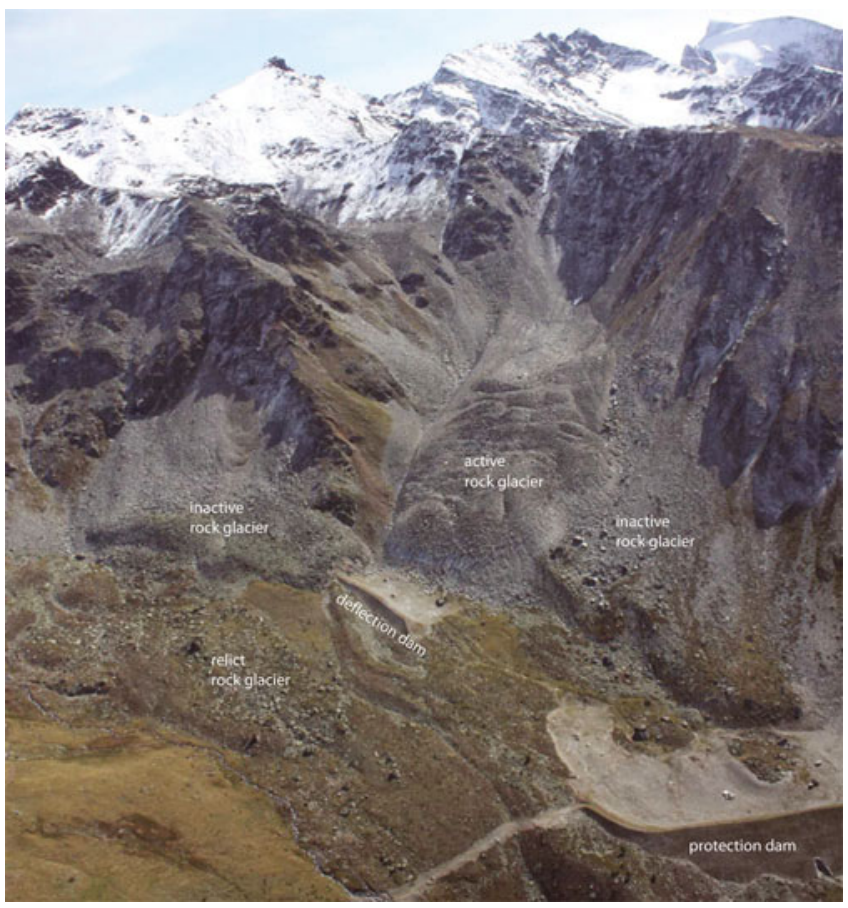

Fig. 8. Avalanche deflection and protection dams constructed in contact with relict, inactive and active viscous flow features of mountain permafrost, i.e. striking landforms resulting from cumulative straining by long-term creep of ice-rich ice-rock mixtures (rock glaciers and 'rock-glacierized' moraines) in the Turtmann Valley, Valais Alps. The active rock glacier in the centre of the image moves at about $1-3 \mathrm{~m} \mathrm{a}^{-1}$ and the front has advanced $\sim 60 \mathrm{~m}$ between 1975 and 2001 (Roer and others, 2005). This activity has been accompanied by the development of numerous crevasses or rupture-like structures at its surface. (Photo from helicopter: I. Gärtner-Roer 2008.)

methods were, and still are, applied to obtain quantitative information on horizontal and vertical surface movements (Roer, 2005). Deformation surveys in boreholes have shown that, at least for rock glaciers moving at rates up to a few tens of $\mathrm{cm} \mathrm{a}^{-1}$, a large part of the surface displacement develops in a 'shear horizon' at depth within the rock glacier permafrost (e.g. Arenson and others, 2002). Within the past decade and rather unexpectedly, a growing number of carefully monitored rock glaciers in the European Alps have indicated strikingly increased rates of surface displacements since the 1990s (Fig. 9), possibly due to a significant rise in permafrost temperature (Roer, 2005; Kääb and others, 2007) and/or to an increase in liquid water content (Ikeda and others, 2008). However, strong interannual changes in horizontal velocities were also shown to occur regionally with a similar rate and a clear synchronism, independent of the size and the activity of the rock glaciers and seemingly reflecting a short-term response to varying ground surface temperatures (Delaloye and others, 2008, 2010b; Nötzli and Vonder Mühll, 2010). In addition, the velocity of many rock glaciers shows significant seasonal rhythms (e.g. Haeberli 1985; Kääb and others, 2007; Delaloye and others, 2010a). Even though the factors controlling the changes are not known in detail, they appear to be related to external factors (e.g. summer air temperature, development of the seasonal snow cover).

In addition to the process changes, the warming and/or thawing of creeping permafrost has a major influence on

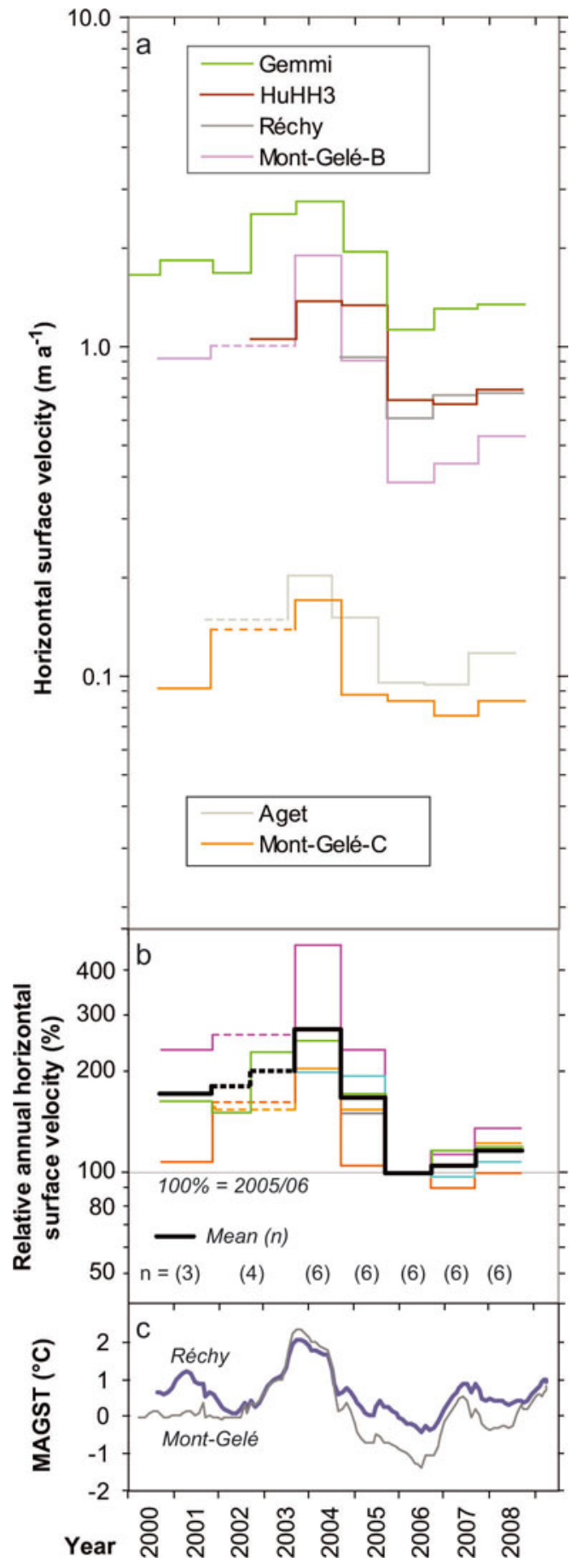

Fig. 9. Combination of horizontal surface velocity and ground surface temperature (from mini-logger measurements) for a number of active rock glaciers in the Swiss Alps. Slightly modified from Nötzli and Vonder Mühll (2010).

slope stability. In this context, several destabilized rock glaciers are currently under investigation in the European Alps (Roer and others, 2008; Delaloye and others, 2010b). These landforms are characterized by horizontal velocities accelerating by orders of magnitude to several $\mathrm{m} \mathrm{a}^{-1}$ or even $>100 \mathrm{~m} \mathrm{a}^{-1}$ and may show crevasse-like features or scarps indicating shear and rupture mechanisms similar to those known for rotational landslides. Interpretation of multitemporal aerial images back to the 1960s indicates that for some rock glaciers the distinct changes in geometry and kinematics had already started several decades ago (Roer 

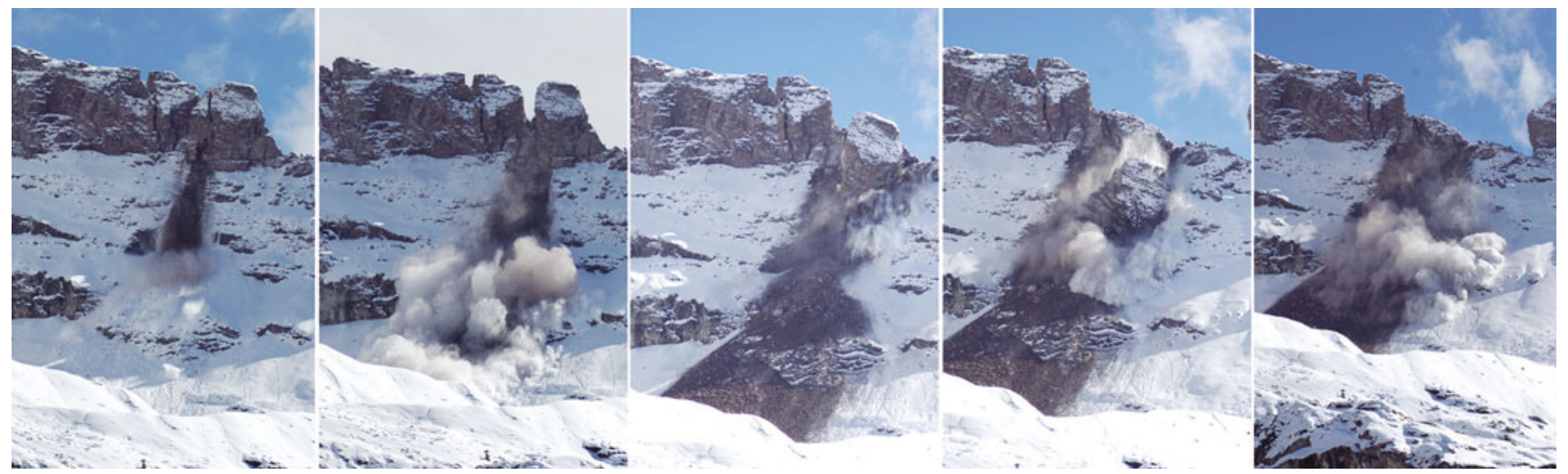

Fig. 10. Failing rock pillar from the Gross Chärpf, Switzerland, in autumn 2007. On the north flank of the Chärpf, warm permafrost likely exists according to the Swiss Permafrost Map (FOEN, 2006). (Photos: O. Adolph, 18 September 2007.)

and others, 2008) and cannot be simply explained by a recent sharp increase in permafrost temperature.

In view of the latest findings regarding creep of ice-rich permafrost, the main current and future challenge is the thorough understanding of ongoing processes in a rheological context. Thermally induced processes leading to a rheological response must be described and modelled including corresponding short-term reaction and long-term response characteristics. The possibility of process combinations or transitions (e.g. involving permafrost creep and some basal sliding or deformation of water-saturated subpermafrost sediments) has also to be considered. Since rock glaciers represent major sediment storages in high-mountain geosystems, the temporal variations in creep rate influence the sediment transfer rates and thus the geomorphic significance of these landforms (Gärtner-Roer and Nyenhuis, 2010). At a regional scale, the question arises as to whether rock glaciers in mountain regions other than the European Alps, such as the Rocky Mountains, the Andes or the Himalaya, show the same kind of interannual variations in flow velocity and corresponding decadal trends. An internationally coordinated long-term monitoring programme such as has been established at a national level in Switzerland (PERMOS) would represent a major step forward.

\section{SLOPE STABILITY}

In cold mountain ranges, bedrock slopes often constitute a large proportion of the total permafrost area. Here changes within ice-bonded discontinuities can influence slope stability. This can be inferred from a considerable number of recent rockfall events (Fig. 10) originating in permafrost areas (e.g. Dramis and others, 1995; Haeberli and others, 1997, 2004; Deline, 2002; Noetzli and others, 2003; Gruber and others, 2004; Huggel and others, 2010; Ravanel and others, 2010). While topography, rock properties and structure are usually taken to be the main determinants of slope stability, permafrost may in some cases be important because it can respond rapidly to climate change or human disturbance. Several candidate mechanisms for this connection of temperature and stability via permafrost degradation exist (Gruber and Haeberli, 2007): loss of bonding, ice segregation, volume expansion, increased hydrostatic pressure and the reduction of shear strength. Warming and thawing of permafrost can arise from the direct interaction of the atmosphere and the rock surface or via changes in snow and ice cover (Fischer and others, 2006) and be propagated to depth by heat conduction (Noetzli and Gruber, 2009) or rapidly by heat convection with water flow (A. Hasler and others, unpublished information). Understanding the mechanisms and conditions that produce ice-filled clefts and fissures as well as understanding the environmental conditions and magnitudes of the processes linking temperature and stability are priorities to improve the ability to anticipate zones of future instability (Fischer, 2009).

The stability of frozen slopes containing unlithified material depends on the ice content and the structural interaction between the solid particles in the frozen ground. Frozen talus/debris in mountainous permafrost terrains is typically coarse and often well graded (e.g. Barsch, 1996; Arenson and others, 2002; Nater and others, 2008). Unlike catastrophic failures that may occur in frozen bedrock, such cases are rare for frozen debris slopes. Nater and others (2008) show that a limit equilibrium slope stability analysis can be carried out using a Mohr-Coulomb failure criterion in which the friction angle represents the structural hindrance of the mass of the soil particles, and the cohesion represents the bonding effect of the ice between the soil particles. The effect of ground warming on the shear strength is represented in such a model by an increasing contribution of the friction component and a decreasing contribution of the cohesion. This results in shallower failure surfaces. Due to the latent heat stored in ice-rich frozen grounds, changes in ice contents are very slow, hence the change in the strength and the failure surface are gradual. Nevertheless, slope stability problems related to rock glaciers with rapidly accelerating creep or sliding rates need closer investigation.

Frost heave and thaw consolidation in the active layer cause shallow surface deformation due to gravity, known as solifluction or gelifluction (e.g. Harris and others, 2008; Kern-Lütschg and Harris, 2008). These occur on frozen slopes of unlithified, fine-grained debris where moisture is available. Warming of the ground may affect the depth of thaw and rates of movement because more water can be released from the transient layer (Shur and others, 2005). It can be assumed that prompt and extensive slope instabilities caused by ground warming are unlikely to occur due to the latent heat effects. However, detailed studies that consider the complex periglacial hydrology in mountainous terrain are needed to better understand the stability of these slopes. 


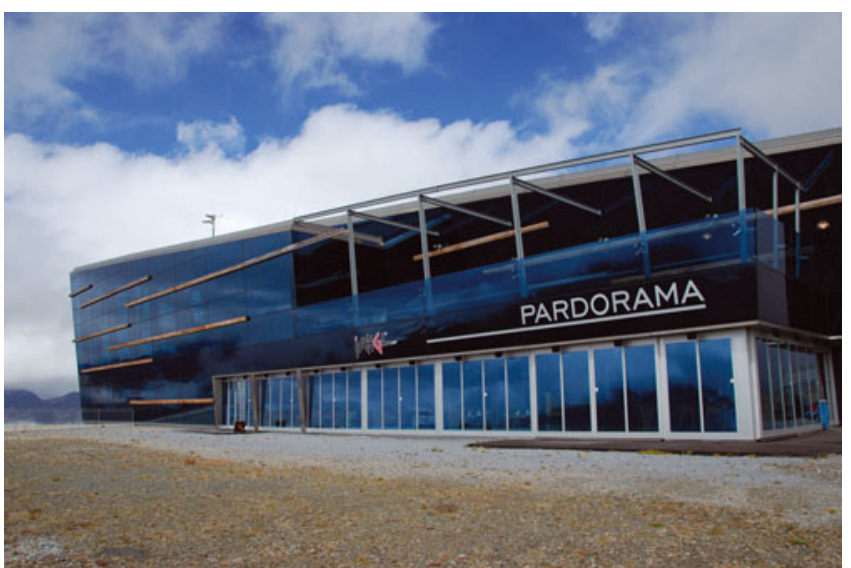

Fig. 11. Mountain restaurant 'Pardorama' in Ischgl, Austrian Alps, located at $2600 \mathrm{~m}$ a.s.I. in permafrost terrain. The building weighs 1400 tons. It is underlain by a three-point foundation which can be raised using hydraulic pumps; steel plates can be inserted below to compensate for settlement of the underlying substrate (currently $\sim 4 \mathrm{~cm} \mathrm{a}^{-1}$ ). (Photo: M. Phillips 2010.)

\section{INFRASTRUCTURE}

The construction and maintenance of infrastructure in mountain permafrost has become increasingly challenging over the past two decades, principally due to changing subsurface conditions in ice-bearing terrain (Bommer and others, 2010). Rising temperatures, varying snow-cover regimes and extreme events such as summer heatwaves have had discernible effects on the stability of Alpine infrastructure anchored in permafrost; in some cases, increasing creep rates and differential settlement induced by the warming and thawing of ground ice have caused irreversible damage to certain structures (Arenson and others, 2009). The occurrence of natural hazards, such as rockfall from thawing rock walls (section 9), is also an increasing threat to mountain infrastructure.

Whereas permafrost-related challenges were addressed, and monitoring techniques developed, in an exemplary fashion for large construction sites at tourism hot spots in the Alps (e.g. the 'Chli Matterhorn' cable car (Keusen and Haeberli, 1983) and the infrastructure on Jungfraujoch (Steiner and others, 1996)), problems have arisen with other infrastructure such as avalanche defence structures, ski lifts and cable-car stations at sites where the geotechnical properties of the ground were less well known or where they changed unpredictably during the design life of the structure (Phillips and others, 2007; Phillips and Margreth, 2008). As a result, some structures have had to be rebuilt or repaired, incurring significant costs.

Although numerous technical recommendations for the construction and maintenance of infrastructure exist in highlatitude permafrost regions (e.g. Instanes and others, 2005) and despite the ongoing generation and evaluation of new permafrost investigation techniques and construction methods, there has been a lack of guidelines for high-elevation permafrost regions. Recently developed practical recommendations emphasize the importance of carrying out a detailed site investigation with suitable monitoring techniques, of avoiding ice-bearing substrates, of applying appropriate construction techniques and of taking into account potential changes in the geotechnical characteristics of the substrate during the design life of mountain infrastructure (Bommer and others, 2010).

In the future, technical developments such as the use of flexible structures (e.g. floating foundations, adaptable three-point foundations, laterally adjustable pylons; Fig. 11), substrate improvement techniques or enhanced insulation and cooling systems will be applied more widely. Improved permafrost detection and monitoring techniques (Hasler and others, 2008; Hilbich and others, 2009), geotechnical laboratory investigations (Arenson and others 2007) and physical and numerical modelling methods (Davies and others, 2003; Noetzli, 2008) allow specific site characteristics to be analysed in advance. The impacts of construction work, infrastructure use and changes in the substrate can therefore be evaluated and predicted during the planning phase. The need for multidisciplinary communication (Haeberli, 1992) between the various parties involved has been clearly recognized and is one of the most important aspects in the planning of successful engineering projects.

\section{CLIMATE-RELATED MONITORING}

Extensive monitoring activities are undertaken today with the general aim of documenting the distribution, state and changes of mountain permafrost on a long-term basis. Systematic long-term monitoring of mountain permafrost essentially began somewhat more than two decades ago with the installation of borehole temperature observations in the active rock glacier Corvatsch-Murtèl, Swiss Alps, in 1987 (Vonder Mühll and Haeberli, 1990) and is increasingly undertaken in many Alpine (Nötzli and Vonder Mühll, 2010; Schoeneich and others, 2010) and Nordic (Isaksen and others, 2007b) countries and in central Asia (Zhao and others, 2010). Metadata are currently reported to the international Global Terrestrial Network for Permafrost (GTN-P) of the Global Climate/Terrestrial Observing System (GCOS/GTOS). In the near future, GTN-P will also start receiving measured temperatures.

Although observed parameters and techniques applied to lowland permafrost in general also apply to mountain areas, specific aspects need to be considered that relate to steep topography and the strong spatial heterogeneity of determining factors. These aspects are tackled within European monitoring programmes: on a continental scale through PACE (Harris and others, 2001) and on a national level particularly through PERMOS in Switzerland (Nötzli and Vonder Mühll, 2010) and NORPERM in Norway (Christiansen and others, 2010). In addition to the general objective of monitoring and documentation, these programmes promise to contribute importantly to alpine permafrost research through their long-term infrastructure and advanced monitoring strategies. Approaches to the long-term documentation of mountain permafrost have constantly been, and are continuing to be, subject to adaptations based on new findings and experiences. In such a young sub-discipline, operational monitoring requires the development of new, sound monitoring strategies along with standards for processing, quality control, archiving and reporting within national and international networks, as well as for defining key parameters for observation and acquisition of the necessary data.

The cornerstones of all permafrost-monitoring activities are ground temperatures measured in boreholes. In deep 


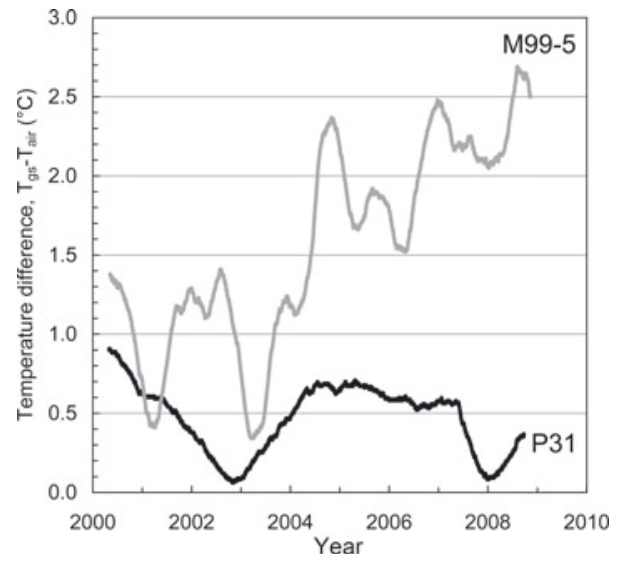

Fig. 12. Differences (surface offset) between MAGST and MAAT during the observation period at PACE drill site Juvvasshøe (P31) in southern Norway, having thin or no snow cover, compared with a site in the mountain slope below (M99-5) with more snow. For the latter site, effects of increased snow depths seem to be the most important factor for observed changes in the surface offset.

boreholes, only a few years are required to calculate a rate of warming at, for example, the permafrost table. So far, however, few observations and analyses exist on the longterm variability in mean ground surface temperature (MGST) and mean ground temperature (MGT) on a local scale, and little is documented about the long-term effects of changes in snow cover and MAAT on the thermal regime in mountain permafrost. In order to account for the high spatial variability (Fig. 12), small temperature-logging devices scattered in distinct topographic settings and surface cover throughout a region are invaluable because they greatly complement borehole measurements. Furthermore, the extrapolation of point measurements to assess permafrost thickness and extent is not straightforward; modelling techniques that account for the spatial variability, 3-D pattern and transient effects are being developed (e.g. Noetzli and Gruber, 2009; section 5), but their operational application remains limited.

Measurements of additional properties to ground temperature (e.g. changes in ice content and permafrost creep) lead to a more comprehensive view of changes in mountain permafrost, but their joint interpretation has only just started. A combined geophysical and thermal monitoring approach using ERT and borehole temperature data has been developed recently (Hauck, 2002; Krautblatter and Hauck, 2007; Hilbich and others, 2009). Latent heat has a major influence on changes in frozen ground, and corresponding changes in unfrozen water content can be detected by ERT monitoring (Fig. 7; Hilbich and others, 2008). Analysis of an 8 year study at Schilthorn has highlighted a much more severe impact of the hot European summer of 2003 on the permafrost than assumed from borehole temperatures alone (Hilbich and others, 2008). Another recent analysis, based on a 10 year record of direct temperature measurements and repeated ERT near Juvvasshøe, Norway, (Fig. 12) indicates the complete degradation of permafrost, which was still present in 1999. Similarly, changes in creep velocities during past years can be interpreted together with changes in unfrozen water content or subsurface temperatures (sections 8 and 9).

Considerable mass movements that occur in high mountains are possibly related to the presence and thermal state of permafrost (sections 8 and 9). Monitoring

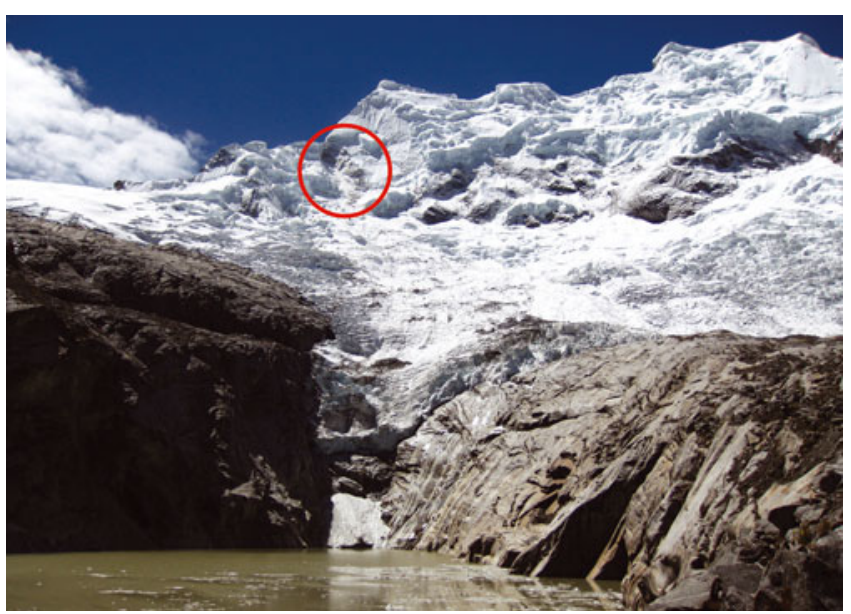

Fig. 13. Laguna 513 and Nevado Hualcán (6104 m a.s.l.), Cordillera Blanca, Peru. On 10 April 2010, a rock/ice avalanche started at $\sim 5400$ ma.s.l. (red circle) from the steep wall with warm permafrost and probably polythermal hanging glaciers, and caused a push-wave at Laguna 513 (4428 ma.s.l.), spilling probably twice over the freeboard of $\sim 20 \mathrm{~m}$, which had been artificially enlarged in 1993 as a hazard prevention measure, and causing damage at the town of Carhuaz. (Photo: W. Haeberli, 15 July 2010.)

increasingly focuses on their documentation (Nötzli and Vonder Mühll, 2010), especially in the densely populated European Alps where observations include numerous smaller and also occasional large rockfall events from periglacial areas and a significant acceleration of many rock glaciers (e.g. Kääb and others, 2007; Delaloye and others, 2008). The joint interpretation of the various observation elements bears potential for a more comprehensive view on mountain permafrost changes but has only just started. Corresponding strategies for analyses are currently being developed.

\section{FURTHER ISSUES AND PERSPECTIVES}

Other fields of study such as the origin and physical characteristics of subsurface ice, prominently reflected in electrical d.c. resistivity soundings (Haeberli and Vonder Mühll, 1996; Kneisel and others, 2000; Kneisel, 2004), or the use of relic features of permafrost creep for paleoclimatic reconstructions in high-mountain areas (Frauenfelder and others, 2001), are still largely unexplored. In view of impacts from current atmospheric warming on mountain permafrost, a general and most important goal can be envisaged for future research on mountain permafrost (Haeberli and Gruber, 2008): a holistic understanding based on quantitative knowledge for applied research, i.e. a broad understanding of all permafrost and its role in mountain landscapes. The multitude of complex interactions between glaciers and permafrost, for instance, offers fascinating and important research avenues (Wegmann and others, 1998; Haeberli, 2005; Kneisel and Kääb, 2007) but so far remains neglected. An integrated and quantitative view of glaciers and permafrost is especially needed in assessment and protection work concerning natural hazards in cold mountains (Haeberli and others, 2001, 2002; Kääb and others, 2005; Huggel, 2009; Huggel and others, 2010). The use of quantitative methods is therefore necessary to understand processes and phenomena of increasing complexity, as well 
as situations which rapidly develop far beyond historical and even Holocene precedence. A recent example is the rock/ ice avalanche at Nevado Hualcán (6104 m a.s.I.), Cordillera Blanca, Peru (Fig. 13). The growing interest in perennially frozen ground in cold mountain ranges is justified, and the rapid progress in this young research field is timely and most welcome.

\section{ACKNOWLEDGEMENTS}

We are grateful to many colleagues in the permafrost community for a fascinating and continued common learning process. B. Etzelmüller and B. Hallet provided constructive feedback to the present contribution.

\section{REFERENCES}

Andersland, O.B. and B. Ladanyi. 2004. An introduction to frozen ground engineering. Second edition. Hoboken, NJ, Wiley.

Arenson, L.U. and D.C. Sego. 2006. The effect of salinity on the freezing of coarse-grained sands. Can. Geotech. J., 43(3), 325337.

Arenson, L.U. and S.M. Springman. 2005a. Mathematical descriptions for the behaviour of ice-rich frozen soils at temperatures close to $0^{\circ} \mathrm{C}$. Can. Geotech. J., 42(2), 431-442.

Arenson, L.U. and S.M. Springman. 2005b. Triaxial constant stress and constant strain rate tests on ice-rich permafrost samples. Can. Geotech. J., 42(2), 412-430.

Arenson, L., M. Hoelzle and S. Springman. 2002. Borehole deformation measurements and internal structure of some rock glaciers in Switzerland. Permafrost Periglac. Process., 13(2), 117-135.

Arenson, L.U., M.M. Johansen and S.M. Springman. 2004. Effects of volumetric ice content and strain rate on shear strength under triaxial conditions for frozen soil samples. Permafrost Periglac. Process., 15(3), 261-271.

Arenson, L.U., S.M. Springman and D.C. Sego. 2007. The rheology of frozen soils. Appl. Rheol., 17(1), 1-14.

Arenson, L.U., M. Phillips and S.M. Springman. 2009. Geotechnical consideration and technical solutions for infrastructure in mountain permafrost. In Krugger, M.I. and H.P. Stern, eds. New permafrost and glacier research. Hauppauge, NY, Nova, 3-50.

Barnes, P., D. Tabor and J.C.F. Walker. 1971. The friction and creep of polycrystalline ice. Proc. R. Soc. London, Ser. A, 324(1557), 127-155.

Barsch, D. 1978. Active rock glaciers as indicators for discontinuous alpine permafrost: an example from the Swiss Alps. In Brown, R.J.E., ed. Proceedings of the 3rd International Conference on Permafrost, 10-13 July, Edmonton, Alberta, Canada, Vol. 1. Ottawa, Ont., National Research Council of Canada, 349-353.

Barsch, D. 1992. Permafrost creep and rock glaciers. Permafrost Periglac. Process., 3(3), 175-188.

Barsch, D. 1996. Rockglaciers: indicators for the present and former geoecology in high mountain environments. Berlin, etc., Springer-Verlag.

Barton, N. and V. Choubey. 1977. The shear strength of rock joints in theory and practice. Rock Mech. Rock Eng., 10(1-2), 1-54.

Bernhard, L., F. Sutter, W. Haeberli and F. Keller. 1998. Processes of snow/permafrost-interactions at a high-mountain site, Murtèl/ Corvatsch, eastern Swiss Alps. In Lewkowicz, A.G. and M. Allard, eds. Proceedings of the 7th International Conference on Permafrost, 23-27 June 1998, Yellowknife, N.W.T., Canada, Vol. 1. Sainte-Foy, Qué, Université Laval. Centre d'Études Nordiques, 35-41. (Collection Nordicana 57.)

Bommer, C., M. Phillips and L.U. Arenson. 2010. Practical recommendations for planning, constructing and maintaining infrastructure in mountain permafrost. Permafrost Periglac. Process., 21(1), 97-104.

Bonnaventure, P.P. and A.G. Lewkowicz. 2008. Mountain permafrost probability mapping using the BTS method in two climatically dissimilar locations, northwest Canada. Can. J. Earth Sci., 45(4), 443-455.

Brown, W.H. 1925. A probable fossil glacier. J. Geol., 33(4), 464-466.

Christiansen, H.H. and 17 others. 2010. The thermal state of permafrost in the Nordic area during the International Polar Year 2007-2009. Permafrost Periglac. Process., 21(2), 156-181.

Dall'Amico, M., S. Endrizzi, S. Gruber and R. Rigon. 2010. An energy-conserving model of freezing variably-saturated soil. Cryos. Discuss., 4(3), 1243-1276.

Davies, M.C.R., O. Hamza, B.W. Lumsden and C. Harris. 2000. Laboratory measurement of the shear strength of ice-filled rock joints. Ann. Glaciol., 31, 463-467.

Davies, M.C.R., O. Hamza and C. Harris. 2003. Physical modelling of permafrost warming in rock slopes. In Phillips, M., S.M. Springman and L.U. Arenson, eds. Proceedings of the 8th International Conference on Permafrost, 21-25 July 2003, Zürich, Switzerland, Vol. 1. Lisse, Swets \& Zeitlinger, 169-174.

Delaloye, R. and C. Lambiel. 2005. Evidence of winter ascending air circulation throughout talus slopes and rock glaciers situated in the lower belt of alpine discontinuous permafrost (Swiss Alps). Nor. Geogr. Tidsskr./Nor. J. Geogr., 59(2), 194-203.

Delaloye, R., E. Reynard, C. Lambiel, L. Marescot and R. Monnet. 2003. Thermal anomaly in a cold scree slope (Creux du Van, Switzerland). In Phillips, M., S.M. Springman and L.U. Arenson, eds. Proceedings of the 8th International Conference on Permafrost, 21-25 July 2003, Zürich, Switzerland, Vol. 1. Lisse, Swets \& Zeitlinger, 175-180.

Delaloye, R. and 14 others. 2008. Recent interannual variations of rock glacier creep in the European Alps. In Kane, D.L. and K.M. Hinkel, eds. Proceedings of the 9th International Conference on Permafrost, 29 June-3 July 2008, Fairbanks, Alaska. Fairbanks, AK, Institute of Northern Engineering, 343-348.

Delaloye, R., C. Lambiel and I. Gärtner-Roer. 2010a. Overview of rock glacier kinematics research in the Swiss Alps: seasonal rhythm, interannual variations and trends over several decades. Geogr. Helv., 65(2), 135-145.

Delaloye, R., S. Morard, D. Abbet and C. Hilbich. 2010b. The slump of the Grabengufer Rock Glacier (Swiss Alps). In Proceedings of the 3rd European Conference on Permafrost (EUCOP III), 13-17 June 2010, Svalbard, Norway. Abstract Book, 157.

Deline, P. 2002. Etude géomorphologique des interactions écroulements rocheux/glaciers dans la haute montagne alpine (versant sud-est du massif du Mont Blanc). (PhD thesis, Université de Savoie.)

Dramis, F., M. Govi, M. Guglielmin and G. Mortara. 1995. Mountain permafrost and slope instability in the Italian Alps: the Val Pola landslide. Permafrost Periglac. Process., 6(1), 73-82.

Etzelmüller, B., I. Berthling and J.L. Sollid. 2003. Aspects and concepts on the geomorphological significance of Holocene permafrost in southern Norway. Geomorphology, 52(1-2), 87-104.

Etzelmüller, B., H. Farbrot, A. Guðmundsson, O. Humlum, O.E. Tveito and H. Björnsson. 2007. The regional distribution of mountain permafrost in Iceland. Permafrost Periglac. Process., 18(2), 185-199.

Federal Office for the Environment (FOEN). 2006. Hinweiskarte Permafrost Schweiz. Bern, Federal Office for the Environment.

Fisch, W., Sr, W. Fisch, Jr and W. Haeberli. 1978. Electrical D.C. resistivity soundings with long profiles on rock glaciers and moraines in the Alps of Switzerland. Z. Gletscherkd. Glazialgeol., 13(1-2), 239-260.

Fischer, L. 2009. Slope instabilities on perenially frozen and glacierised rock walls: multi-scale observations, analyses and modelling. Schr. Phys. Geogr., Univ. Zürich 58. 
Fischer, L., A. Kääb, C. Huggel and J. Noetzli. 2006. Geology, glacier retreat and permafrost degradation as controlling factors of slope instabilities in a high-mountain rock wall: the Monte Rosa east face. Natur. Hazards Earth Syst. Sci. (NHESS), 6(5), 761-772.

Fish, A.M. 1985. Creep strength, strain rate, temperature and unfrozen water relationship in frozen soil. In Kinosita, S. and M. Fukuda, eds. Proceedings of the 4th International Symposium on Ground Freezing (ISGF), 5-7 August 1985, Sapporo, Japan, Vol. 2. Rotterdam, A.A. Balkema/Sapporo, Hokkaido University Press, 29-36.

Fisher, J.E. 1953. The cold ice tunnel on the Silbersattel, Monte Rosa. J. Glaciol., 2(13), 193, 195-196.

Frauenfelder, R., W. Haeberli, M. Hoelzle and M. Maisch. 2001. Using relict rockglaciers in GIS-based modelling to reconstruct Younger Dryas permafrost distribution patterns in the Err-Julier area, Swiss Alps. Nor. Geogr. Tidsskr./Nor. J. Geogr., 55(4), 195-202.

Fujii, Y. and K. Higuchi. 1978. Distribution of alpine permafrost in the Northern Hemisphere and its relation to air temperature. In Proceedings of the 3rd International Conference on Permafrost, 10-13 July 1978, Edmonton, Alberta, Canada, Vol. 1. Ottawa, Ont., National Research Council of Canada, 366-371.

Gärtner-Roer, I. and M. Nyenhuis. 2010. Volume estimation, kinematics and sediment transfer rates of active rockglaciers in the Turtmann Valley, Switzerland. In Otto, J.-C. and R. Dikau, eds. Landform - Structure, Evolution, Process Control. Proceedings of the International Symposium on Landform. Heidelberg, Springer, 185-198. (Lecture Notes in Earth Sciences 115.)

Goering, D.J. and P. Kumar. 1996. Winter-time convection in opengraded embankments. Cold Reg. Sci. Technol., 24(1), 57-74.

Gorbunov, A.P. 1978. Permafrost in the mountains of central Asia. In Proceedings of the 3rd International Conference on Permafrost, 10-13 July 1978, Edmonton, Alberta, Canada, Vol. 1. Ottawa, Ont., National Research Council of Canada, 372-377.

Goughnour, R.R. and O.B. Andersland. 1968. Mechanical properties of a sand-ice system. J. Soil Mech. Found. Div., ASCE, 94(SM4), 923-950.

Gruber, S. and W. Haeberli. 2007. Permafrost in steep bedrock slopes and its temperature-related destabilization following climate change. J. Geophys. Res., 112(F2), F02S18. (10.1029/ 2006JF000547.)

Gruber, S. and W. Haeberli. 2009. Mountain permafrost. In Margesin, R., ed. Permafrost soils. Berlin, etc., Springer, 33-44.

Gruber, S. and M. Hoelzle. 2008. The cooling effect of coarse blocks revisited: a modeling study of a purely conductive mechanism. In Kane, D.L. and K.M. Hinkel, eds. Proceedings of the 9th International Conference on Permafrost, 29 June-3 July 2008, Fairbanks, Alaska, Vol. 1. Fairbanks, AK, Institute of Northern Engineering, 557-561.

Gruber, S., L. King, T. Kohl, T. Herz, W. Haeberli and M. Hoelzle. 2004a. Interpretation of geothermal profiles perturbed by topography: the alpine permafrost boreholes at Stockhorn Plateau, Switzerland. Permafrost Periglac. Process., 15(4), 349-357.

Gruber, S., M. Hoelzle and W. Haeberli. 2004b. Permafrost thaw and destabilization of Alpine rock walls in the hot summer of 2003. Geophys. Res. Lett., 31(13), L13504. (10.1029/ 2004GL020051.)

Günzel, F.K. 2008. Shear strength of ice-filled rock joints. In Kane, D.L. and K.M. Hinkel, eds. Proceedings of the 9th International Conference on Permafrost, 29 June-3 July 2008, Fairbanks, Alaska, Vol. 1. Fairbanks, AK, Institute of Northern Engineering, 581-586.

Guodong, C. and F. Dramis. 1992. Distribution of mountain permafrost and climate. Permafrost Periglac. Process., 3(2), 83-91.

Haeberli, W. 1978. Special aspects of high mountain permafrost methodology and zonation in the Alps. In Brown, R.J.E., ed. Proceedings of the 3rd International Conference on Permafrost,
10-13 July 1978, Edmonton, Alberta, Canada, Vol. 1. Ottawa, Ont., National Research Council of Canada, 379-384.

Haeberli, W. 1985. Creep of mountain permafrost: internal structure and flow of Alpine rock glaciers. Mitt. VAW/ETH 77.

Haeberli, W. 1992. Construction, environmental problems and natural hazards in periglacial mountain belts. Permafrost Periglac. Process., 3(2), 111-124.

Haeberli, W. 2005. Investigating glacier-permafrost relationships in high-mountain areas: historical background, selected examples and research needs. In Harris, C. and J.B. Murton, eds. Cryospheric systems: glaciers and permafrost. London, Geological Society of London, 29-37. (Special publication 242.)

Haeberli, W. and M. Funk. 1991. Borehole temperatures at the Colle Gnifetti core-drilling site (Monte Rosa, Swiss Alps). J. Glaciol., 37(125), 37-46.

Haeberli, W. and S. Gruber. 2008. Research challenges for permafrost in steep and cold terrain: an Alpine perspective. In Kane, D.L. and K.M. Hinkel, eds. Proceedings of the 9th International Conference on Permafrost, 29 June-3 July 2008, Fairbanks, Alaska, Vol. 1. Fairbanks, AK, Institute of Northern Engineering, 597-605.

Haeberli, W. and S. Gruber. 2009. Gobal warming and mountain permafrost. In Margesin, R., ed. Permafrost soils. Berlin, etc., Springer, 205-218.

Haeberli, W. and D. Vonder Mühll. 1996. On the characteristics and possible origins of ice in rock glacier permafrost. Z. Geomorph., 104, 43-57.

Haeberli, W., G.D. Cheng, A.P. Gorbunov and S.A. Harris. 1993. Mountain permafrost and climatic change. Permafrost Periglac. Process., 4(2), 165-174.

Haeberli, W., M. Wegmann and D. Vonder Mühll. 1997. Slope stability problems related to glacier shrinkage and permafrost degradation in the Alps. Eclogae Geol. Helv., 90, 407-414.

Haeberli, W. and 7 others. 1999. Pollen analysis and ${ }^{14} \mathrm{C}$ age of moss remains in a permafrost core recovered from the active rock glacier Murtèl-Corvatsch, Swiss Alps: geomorphological and glaciological implications. J. Glaciol., 45(149), 1-8.

Haeberli, W., A. Kääb, D. Vonder Mühll and P. Teysseire. 2001. Prevention of outburst floods from periglacial lakes at Grubengletscher, Valais, Swiss Alps. J. Glaciol., 47(156), 111-122.

Haeberli, W. and 7 others. 2002. A surge-type movement at Ghiacciaio del Belvedere and a developing slope instability in the east face of Monte Rosa, Macugnaga, Italian Alps. Nor. Geogr. Tidsskr., 56(2), 104-111.

Haeberli, W. and 7 others. 2004. The Kolka-Karmadon rock/ice slide of 20 September 2002: an extraordinary event of historical dimensions in North Ossetia, Russian Caucasus. J. Glaciol., 50(171), 533-546.

Haeberli, W. and 10 others. 2006. Permafrost creep and rock glacier dynamics. Permafrost Periglac. Process., 17(3), 189-214.

Haefeli, R. and F. Brentani. 1955. Observations in a cold ice cap. Part I. J. Glaciol., 2(18), 571-581.

Harris, C., W. Haeberli, D. Vonder Mühll and L. King. 2001. Permafrost monitoring in the high mountains of Europe: the PACE Project in its global context. Permafrost Periglac. Process., 12(1), 3-11.

Harris, C. and 9 others. 2003. Warming permafrost in European mountains. Global Planet. Change, 39(3-4), 215-225.

Harris, C., M.A. Kern-Lütschg, J. Murton, M. Font, M. Davies and F. Smith. 2008. Solifluction processes on permafrost and nonpermafrost slopes: results of a large-scale laboratory simulation. Permafrost Periglac. Process., 19(4), 359-378.

Harris, C. and 21 others. 2009. Permafrost and climate in Europe: monitoring and modelling thermal, geomorphological and geotechnical responses. Earth-Sci. Rev., 92(3-4), 117-171.

Harris, S.A. and R.J.E. Brown. 1978. Plateau Mountain: a case study of alpine permafrost in the Canadian Rocky Mountains. In Proceedings of the Third International Conference on Permafrost, 10-13 July 1978, Edmonton, Alberta, Vol. 1. Ottawa, Ont., National Research Council of Canada, 386-391. 
Harris, S.A. and A.E. Corte. 1992. Interactions and relations between mountain permafrost, glaciers, snow and water. Permafrost Periglac. Process., 3(2), 103-110.

Harris, S.A. and D.E. Pedersen. 1998. Thermal regimes beneath coarse blocky materials. Permafrost Periglac. Process., 9(2), 107-120.

Hasler, A., I. Talzi, J. Beutel, C. Tschudin and S. Gruber. 2008. Wireless sensor networks in permafrost research: concept, requirements, implentation, and challenges. In Kane, D.L. and K.M. Hinkel, eds. Proceedings of the 9th International Conference on Permafrost, 29 June-3 July 2008, Fairbanks, Alaska, Vol. 1. Fairbanks, AK, Institute of Northern Engineering, 669-674.

Hauck, C. 2002. Frozen ground monitoring using DC resistivity tomography. Geophys. Res. Lett., 29(2), 2016. (10.1029/ 2002GL014995.)

Hauck, C. and C. Kneisel. 2008. Applied geophysics in periglacial environments. Cambridge, etc., Cambridge University Press.

Hauck, C., M. Bach and C. Hilbich. 2008. A four-phase model to quantify subsurface ice and water content in permafrost regions based on geophysical data sets. In Kane, D.L. and K.M. Hinkel, eds. Proceedings of the 9th International Conference on Permafrost, 29 June-3 July, 2008, Fairbanks, Alaska, Vol. 1. Fairbanks, AK, Institute of Northern Engineering, 675-680.

Hilbich, C. 2009. Geophysical monitoring systems to assess and quantify ground ice evolution in mountain permafrost. (PhD thesis, University of Jena.)

Hilbich, C. and 7 others. 2008. Monitoring mountain permafrost evolution using electrical resistivity tomography: a 7-year study of seasonal, annual, and long-term variations at Schilthorn, Swiss Alps. J. Geophys. Res., 113(F1), F01S90. (10.1029/ 2007JF000799.)

Hilbich, C., L. Marescot, C. Hauck, M.H. Loke and R. Mäusbacher. 2009. Applicability of electrical resistivity tomography monitoring to coarse blocky and ice-rich permafrost landforms. Permafrost Periglac. Process., 20(3), 269-284.

Hivon, E.G. and D.C. Sego. 1995. Strength of frozen saline soils. Can. Geotech. J., 32(2), 336-354.

Hoelzle, M., C. Mittaz, B. Etzelmüller and W. Haeberli. 2001. Surface energy fluxes and distribution models of permafrost in European mountain areas: an overview of current developments. Permafrost Periglac. Process., 12(1), 53-68.

Huggel, C. 2009. Recent extreme slope failures in glacial environments: effects of thermal perturbation. Quat. Sci. Rev., 28(11-12), 1119-1130.

Huggel, C. and 8 others. 2010. Recent and future warm extreme events and high-mountain slope stability. Philos. Trans. R. Soc. London, Ser. A, 368(1919), 2435-2459.

Ikeda, A., N. Matsuoka and A. Kääb. 2008. Fast deformation of perennially frozen debris in a warm rock glacier in the Swiss Alps: an effect of liquid water. J. Geophys. Res., 113(F1), F01021. (10.1029/2007JF000859.)

Instanes, A. and 6 others. 2005. Infrastructure: buildings, support systems, and industrial facilities. In Arctic Climate Impact Assessment, Arctic climate impact assessment: scientific report. Cambridge, etc., Cambridge University Press, 907-944.

Isaksen, K., R.E. Benestad, C. Harris and J.L. Sollid. 2007a. Recent extreme near-surface permafrost temperatures on Svalbard in relation to future climate scenarios. Geophys. Res. Lett., 34(17), L17502. (10.1029/2007GL031002.)

Isaksen, K., J.L. Sollid, P. Holmlund and C. Harris. 2007b. Recent warming of mountain permafrost in Svalbard and Scandinavia. J. Geophys. Res., 112(F2), F02S04. (10.1029/2006JF00052.)

Jin, H., S. Li, G. Cheng, S. Wang and X. Li. 2000. Permafrost and climatic change in China. Global Planet. Change, 26(4), 387-404.

Juliussen, H. and O. Humlum. 2008. Thermal regime of openwork block fields on the mountains Elgåhogna and Sølen, centraleastern Norway. Permafrost Periglac. Process., 19(1), 1-18.
Kääb, A., J.M. Reynolds and W. Haeberli. 2005. Glacier and permafrost hazards in high mountains. In Huber, U.M., H.K.M. Bugmann and M.A. Reasoner, eds. Global change and mountain regions: an overview of current knowledge. Dordrecht, Kluwer Academic Publishers, 225-234.

Kääb, A., R. Frauenfelder and I. Roer. 2007. On the response of rockglacier creep to surface temperature increase. Global Planet. Change, 60(1-2), 172-187.

Kane, D.L., K.M. Hinkel, D.J. Goering, L.D. Hinzman and S.I. Outcalt. 2001. Non-conductive heat transfer associated with frozen soils. Global Planet. Change, 29(3-4), 275-292.

Kellerer-Pirklbauer, A., H. Farbrot and B. Etzelmüller. 2007. Permafrost aggradation caused by tephra accumulation over snow-covered surfaces: examples from the Hekla-2000 eruption in Iceland. Permafrost Periglac. Process., 18(3), 269-284.

Kemeny, J. 2003. The time-dependent reduction of sliding cohesion due to rock bridges along discontinuities: a fracture mechanics approach. Rock Mech. Rock Eng., 36(1), 27-38.

Kern-Lütschg, M.A. and C. Harris. 2008. Centrifuge modelling of solifluction processes: displacement profiles associated with one-sided and two-sided active layer freezing. Permafrost Periglac. Process., 19(4), 379-392.

Keusen, H.R. and W. Haeberli. 1983. Site investigation and foundation design aspects of cable car construction in alpine permafrost at the 'Chli Matterhorn', Wallis, Swiss Alps. In Proceedings of the 4th International Conference on Permafrost, 17-22 July 1983, Fairbanks, Alaska. Washington, DC, National Academy Press, 601-605.

King, L., A.P. Gorbunov and M. Evin. 1992. Prospecting and mapping of mountain permafrost and associated phenomena. Permafrost Periglac. Process., 3(2), 73-81.

Kneisel, C. 2004. New insights into mountain permafrost occurrence and characteristics in glacier forefields at high altitude through the application of $2-\mathrm{D}$ resistivity imaging. Permafrost Periglac. Process., 15(3), 221-227.

Kneisel, C. 2006. Assessment of subsurface lithology in mountain environments using 2-D resistivity imaging. Geomorphology, 80(1-2), 32-44.

Kneisel, C. and A. Kääb. 2007. Mountain permafrost dynamics within a recently exposed glacier forefield inferred by a combined geomorphological, geophysical and photogrammetrical approach. Earth Surf. Process. Landf., 32(12), 1797-1810.

Kneisel, C., W. Haeberli and R. Baumhauer. 2000. Comparison of spatial modelling and field evidence of glacier/permafrost relations in an Alpine permafrost environment. Ann. Glaciol., 31, 269-274.

Kneisel, C., C. Hauck, R. Fortier and B. Moorman. 2008. Advances in geophysical methods for permafrost investigations. Permafrost Periglac. Process., 19(2), 157-178.

Koestel, J., A. Kemna, M. Javaux, A. Binley and H. Vereecken. 2008. Quantitative imaging of solute transport in an unsaturated and undisturbed soil monolith with 3-D ERT and TDR. Water Resour. Res., 44(W12), W12411. (10.1029/2007WR006755.)

Krautblatter, M. 2009. Detection and quantification of permafrost change in alpine rock walls and implications for rock instability. (PhD thesis, University of Bonn.)

Krautblatter, M. and D. Draebing. 2010. Pseudo 3-D - P-wave refraction seismic monitoring of permafrost in steep bedrock: laboratory calibration, error assessment and field techniques. Geophys. Res. Abstr., 12, EGU2010-4095.

Krautblatter, M. and D. Funk. 2010. A rock/ice mechanical model for the destabilisation of permafrost rocks and first laboratory evidence for the 'reduced friction hypothesis'. Proceedings of the 3rd European Conference on Permafrost (EUCOP III), 13-17 June 2010, Svalbard, Norway. Abstract Book, 205.

Krautblatter, M. and C. Hauck. 2007. Electrical resistivity tomography monitoring of permafrost in solid rock walls. J. Geophys. Res., 112(F2), F02S20. (10.1029/2006JF000546.)

Krautblatter, M., M., S. Verleysdonk, A. Flores-Orozco and A. Kemna. 2010. Temperature-calibrated imaging of seasonal 
changes in permafrost rock walls by quantitative electrical resistivity tomography (Zugspitze, German/Austrian Alps). J. Geophys. Res., 115(F2), F02003. (10.1029/2008JF001209.)

Lautridou, J.P., B. Francou and K. Hall. 1992. Present-day periglacial processes and landforms in mountain areas. Permafrost Periglac. Process., 3(2), 93-101.

Luetscher, M., P.Y. Jeannin and W. Haeberli. 2005. Ice caves as an indicator of winter climate evolution: a case study from the Jura Mountains. Holocene, 15(7), 982-993.

Lüthi, M.P. and M. Funk. 2001. Modelling heat flow in a cold, highaltitude glacier: interpretation of measurements from Colle Gnifetti, Swiss Alps. J. Glaciol., 47(157), 314-324.

Marchenko, S.S. 2001. A model of permafrost formation and occurrences in the intracontinental mountains. Nor. Geogr. Tidsskr./Nor. J. Geogr., 55(4), 230-234.

Marchenko, S.S., A.P. Gorbunov and V.E. Romanovsky. 2007. Permafrost warming in the Tien Shan mountains, Central Asia. Global Planet. Change, 56(3-4), 311-327.

Mellor, M. 1973. Mechanical properties of rocks at low temperature. In Permafrost: the North American Contribution to the 2nd International Conference on Permafrost, 13-28 July, 1973, Takutsk, U.S.S.R. Washington, DC, National Academy of Sciences, 334-344.

Morard, S., R. Delaloye and C. Lambiel. 2010a. Pluriannual thermal behaviour of low elevation cold talus slopes in western Switzerland. Geogr. Helv., 65(2), 124-134.

Morard, S., M. Bochud and R. Delaloye. 2010b. Rapid changes of the ice mass configuration in the dynamic Diablotins ice cave, Fribourg Prealps, Switzerland. Cryosphere, 4(4), 489-500.

Murton, J.B., R. Peterson and J.C. Ozouf. 2006. Bedrock fracture by ice segregation in cold regions. Science, 314(5802), 1127-1129.

Nater, P., L.U. Arenson and S.M. Springman. 2008. Choosing geotechnical parameters for slope stability assessments in Alpine permafrost soils. In Kane, D.L. and K.M. Hinkel, eds. Proceedings of the 9th International Conference on Permafrost, 29 June3 July 2008, Fairbanks, Alaska, Vol. 1. Fairbanks, AK, Institute of Northern Engineering, 1261-1266.

Nickling, W.G. and L. Bennett. 1984. The shear strength characteristics of frozen coarse granular debris. J. Glaciol., 30(106), 348-357.

Noetzli, J. 2008. Modeling transient three-dimensional temperature fields in mountain permafrost. (PhD thesis, University of Zürich.)

Noetzli, J. and S. Gruber. 2009. Transient thermal effects in Alpine permafrost. Cryosphere, 3(1), 85-99.

Noetzli, J., M. Hoelzle and W. Haeberli. 2003. Mountain permafrost and recent Alpine rock-fall events: a GIS-based approach to determine critical factors. In Phillips, M., S.M. Springman and L.U. Arenson, eds. Proceedings of the 8th International Conference on Permafrost, 21-25 July 2003, Zürich, Switzerland. Zürich, Swets \& Zeitlinger, 827-832.

Noetzli, J., S. Gruber, T. Kohl, N. Salzmann and W. Haeberli. 2007. Three-dimensional distribution and evolution of permafrost temperatures in idealized high-mountain topography. J. Geophys. Res., 112(F2), F02S13. (10.1029/2006JF000545.)

Nötzli, J. and D. Vonder Mühll, eds. 2010. Permafrost in Switzerland 2006/2007 and 2007/2008. Zürich, Swiss Academy of Sciences (SCNAT). Cryospheric Commission. (Glaciological Report (Permafrost) 8/9.)

Nötzli, J., B. Naegeli and D. Vonder Mühll, eds. 2009. Permafrost in Switzerland 2004/2005 and 2005/2006. Zürich, Swiss Academy of Sciences (SCNAT). Cryospheric Commission. (Glaciological Report (Permafrost) 6/7.)

Nötzli, J., S. Gruber and A. von Poschinger. 2010. Modellierung und Messung von Permafrosttemperaturen im Gipfelgrat der Zugspitze, Deutschland. Geogr. Helv., 65(2), 113-123.

Paterson, W.S.B. 1994. The physics of glaciers. Third edition. Oxford, etc., Elsevier.

Phillips, M. and S. Margreth. 2008. Effects of ground temperature and slope deformation on the service life of snow-supporting structures in mountain permafrost: Wisse Schijen, Randa, Swiss
Alps. In Kane, D.L. and K.M. Hinkel, eds. Proceedings of the 9th International Conference on Permafrost, 29 June-3 July 2008, Fairbanks, Alaska, Vol. 2. Fairbanks, AK, Institute of Northern Engineering, 1417-1422.

Phillips, M., F. Ladner, M. Müller, U. Sambeth, J. Sorg and P. Teysseire. 2007. Monitoring and reconstruction of a chairlift midway station in creeping permafrost terrain, Grächen, Swiss Alps. Cold Reg. Sci. Technol., 47(1-2), 32-42.

Phillips, M., E. Zenklusen Mutter, M. Kern-Luetschg and M. Lehning. 2009. Rapid degradation of ground ice in a ventilated talus slope: Flüela Pass, Swiss Alps. Permafrost Periglac. Process., 20(1), 1-14.

Ravanel, L., F. Allignol, P. Deline, S. Gruber and M. Ravello. 2010. Rock falls in the Mont Blanc Massif in 2007 and 2008. Landslides, 7(4), 493-501.

Riseborough, D., N. Shiklomanov, B. Etzelmüller, S. Gruber and S. Marchenko. 2008. Recent advances in permafrost modelling. Permafrost Periglac. Process., 19(2), 137-156.

Rist, A. and M. Phillips. 2005. First results of investigations on hydrothermal processes within the active layer above alpine permafrost in steep terrain. Nor. Geogr. Tidsskr./Nor. J. Geogr., 59(2), 177-183.

Roer, I. 2005. Rockglacier kinematics in a high mountain geosystem. (PhD thesis, University of Bonn.)

Roer, I., A. Kääb and R. Dikau. 2005. Rockglacier acceleration in the Turtmann valley (Swiss Alps): probable controls. Nor. Geogr. Tidsskr./Nor. J. Geogr., 59(2), 157-163.

Roer, I. and 6 others. 2008. Observations and considerations on destabilizing active rock glaciers in the European Alps. In Kane, D.L. and K.M. Hinkel, eds. Proceedings of the 9th International Conference on Permafrost, 29 June-3 July 2008, Fairbanks, Alaska, Vol. 2. Fairbanks, AK, Institute of Northern Engineering, 1505-1510.

Romanovsky, V.E. and 7 others. 2007. Frozen ground. In Eamer, J., ed. The global outlook for ice and snow. Nairobi, United Nations Environment Programme, 181-200.

Romanovsky, V.E., S.L. Smith and H.H. Christiansen. 2010. Permafrost thermal state in the polar Northern Hemisphere during the International Polar Year 2007-2009: a synthesis. Permafrost Periglac. Process., 21(2), 106-116.

Sanderson, T.J.O. 1988. Ice mechanics: risks to offshore structures. London, etc., Graham and Trotman.

Scherler, M., C. Hauck, M. Hoelzle, M. Stähl and I. Völksch. 2010. Meltwater infiltration into the frozen active layer at an alpine permafrost site. Permafrost Periglac. Process., 21(4), 325-334.

Schoeneich, P., X. Bodin, J.-M. Krysiecki, P. Deline and L. Ravanel. 2010. Permafrost in France. Grenoble, PermaFRANCE. (PermaFRANCE Network Report 1.)

Shur, Y., K.M. Hinkel and F.E. Nelson. 2005. The transient layer: implications for geocryology and climate-change science. Permafrost Periglac. Process., 16(1), 5-17.

Springman, S.M. and L.U. Arenson. 2008. Recent advances in permafrost geotechnics. In Kane, D.L. and K.M. Hinkel, eds. Proceedings of the 9th International Conference on Permafrost, 29 June-3 July, 2008, Fairbanks, Alaska, Vol. 2. Fairbanks, AK, Institute of Northern Engineering, 1685-1694.

Steiner, W., H.R. Keusen and U. Graber. 1996. Construction in rock at 3550 metres (Jungfraujoch, Switzerland). In Barla, G., ed. Eurock 96: Proceedings of the Symposium on Prediction and Performance in Rock Mechanics and Rock Engineering, 2-5 September 1996, Torino, Italy. Rotterdam, A.A. Balkema, 543-550.

Vonder Mühll, D. and W. Haeberli. 1990. Thermal characteristics of the permafrost within an active rock glacier (Murtèl/ Corvatsch, Grisons, Swiss Alps). J. Glaciol., 36(123), 151-158.

Wahrhaftig, C. and A. Cox. 1959. Rock glaciers in the Alaska Range. Geol. Soc. Am. Bull., 70(4), 383-436.

Wegmann, M., G.H. Gudmundsson and W. Haeberli. 1998. Permafrost changes in rock walls and the retreat of Alpine 
glaciers: a thermal modelling approach. Permafrost Periglac. Process., 9(1), 23-33.

Yasufuku, N., S.M. Springman, L.U. Arenson and T. Ramholt. 2003. Stress-dilatancy behaviour of frozen sand in direct shear. In Phillips, M., S.M. Springman and L.U. Arenson, eds. Proceedings of the 8th International Conference on Permafrost, 21-25 July 2003, Zürich, Switzerland, Vol. 2. Lisse, Swets \& Zeitlinger, 1253-1258.

Zenklusen Mutter, E., J. Blanchet and M. Phillips. 2010. Analysis of ground temperature trends in Alpine permafrost using generalized least-squares. J. Geophys. Res., 115(F4), F04009. (10.1029/2009JF001648.)

Zhang, T., J.A. Heginbottom, R.G. Barry and J. Brown. 2000. Further statistics on the distribution of permafrost and ground ice in the Northern Hemisphere. Polar Geogr., 24(2), 126-131.

Zhao, L., Q. Wu, S.S. Marchenko and N. Sharkhuu. 2010. Thermal state of permafrost and active layer in Central Asia during the International Polar Year. Permafrost Periglac. Process., 21(2), 198-207. 